Migration Studies - Review of Polish Diaspora nr 4 (174)/2019, http://www.ejournals.eu/Studia-Migracyjne/ DOI: 10.4467/25444972SMPP.19.038.11352

\title{
Próba przeglądu problemów, źródeł i opracowań na temat losów Polek na emigracji przed II wojną światową
}

\author{
ANNA RECZYŃSKA ${ }^{1}$ \\ Uniwersytet Jagielloński
}

Od końca XVIII w. ziemie polskie opuszczały kolejne fale zesłańców, uchodźców politycznych i emigrantów. Były wśród nich również kobiety. Ich udział w ruchach migracyjnych, problemy i doświadczenia podróży oraz zmiany związane z nowym miejscem osiedlenia są jednak w większości opracowań historycznych pomijane i marginalizowane. Wynika to z braku źródeł, z braku szczegółowych badań nad udziałem oraz rolą kobiet w kolejnych falach polskich migracji, ale też z braku zainteresowania tą sferą ze strony historyków. Ostania z wymienionych barier jest przełamywana dopiero od lat 80. XX w., a wcześniejsze opracowania bazują głównie na doświadczeniach mężczyzn. Celem artykułu jest próba ukazania stanu badań dotyczących kolejnych okresów, różnych kierunków oraz zagadnień związanych z migracjami Polek od XIX w. do wybuchu II wojny światowej. Przedstawiona problematyka obejmuje zarówno migracje polityczne, wyjazdy na studia, różne kierunki emigracji zarobkowej jak i przemieszczenia z okresu I wojny światowej. Zestawienie dostępnych danych statystycznych dowodzi stopniowego zwiększania udziału kobiet wśród polskich migrantów. Ich odsetek, koleje losu oraz procesy przemian pozycji w rodzinie a także w lokalnej i ponadlokalnej społeczności etnicznej i poza nią zależały tak od okresu emigracji, kraju oraz miejsca osiedlenia jak i od charakteru podejmowanych zajęć. Ważnym czynnikiem wydaje się także nastawienie i pomoc dla kobiet - imigrantek w krajach ich osiedlenia.

Słowa kluczowe: historia polskich migracji, migracje polskich kobiet, diaspora polska

\section{The Fate of Polish Women in Countries of Emigration Before WWII: A Review of Research Problematics, Source Texts and Scientific Analyses}

Since the end of the 18th century, Former Polish territories had been abandoned by successive waves of deportees, political refugees and emigrants. Among them there were also women. However,

1 Kontakt: anna.reczynska@uj.edu.pl 
their participation in migratory movements, problems and experiences of travel as well as changes related to the new settlement are omitted and marginalized in most historical studies. This results from the lack of sources, lack of detailed research on the participation and role of women in subsequent waves and directions of Polish migration, as well as from the lack of interest in this subject on the part of historians. It should be stressed that the last of these barriers has been broken only since the 1980s. The examples presented here show, however, that the history of Polish emigration is based mainly on the experiences of men.

The aim of the article is to present the state of research concerning subsequent periods, different directions and familiar and less familiar issues related to the migration of Polish women from the 19th century till the outbreak of World War II. The presented issues include political migrations, study trips, various directions of economic emigration (Ruhr, France, USA, Brazil, Canada) as well as relocations from the period of World War I. The comparison of available statistical data shows a gradual increase in the number of women among Polish migrants. Their percentage, the course of fate and the processes of change in their position within the family as well as in the local and supra-local ethnic community and beyond it had been shaped in different ways. They depended both on the period of emigration, the country and place of settlement as well as the nature of the activities undertaken. Another important factor seems to be the attitude and assistance for women-immigrants in the countries of their settlement. This issue, however, still remains in the sphere of suggestions for future researchers, both men and women.

Key words: history of Polish migration, migration of Polish women, Polish diaspora

\section{Wprowadzenie}

W większości polskich fal emigracyjnych, tak jak w wypadku wielu innych ruchów migracyjnych na świecie, o wyjazdach kobiet i mężczyzn decydowały podobne czynniki: polityczne, ekonomiczne, społeczne a najczęściej ich splot, kształtowany dodatkowo motywami indywidualnymi. W przeszłości zwykle mężczyźni wyjeżdżali jako pierwsi. Dopiero po jakimś czasie część z nich sprowadzała rodziny. Kobiety były częściej przedmiotem niż podmiotem decyzji o wyjeździe. Na ogół bały się podróży i życia w nowych warunkach. Decydowała jednak presja społeczna, obawa przed rozpadem rodziny lub utratą podstaw egzystencji. Niektóre z kobiet się buntowały, ale niewiele o tym wiadomo. Historykom brakuje materiałów umożliwiających rekonstrukcję specyficznych problemów, z którymi w przeszłości polskie emigrantki borykały się tak w podróży jak i po przyjeździe do nowego kraju. Relacje źródłowe pozwalają jedynie na rekonstrukcję wycinków ich opinii a także informacji o sukcesach i trudnościach z adaptacją do nowych warunków czy o przejawach aktywności w miejscu osiedlenia. Niewiele jest też opracowań historycznych ukazujących z perspektywy kobiet procesy przemian zachodzących w różnych odłamach polskiej diaspory. Należy przy tym pamiętać, że w każdym kraju sytuacja emigrantek była odmienna i że dodatkowo zachodziło tam wiele różnych zmian.

Historiografia dotycząca migracji z ziem polskich aż do lat 80. XX w. skupiała się niemal wyłącznie na losach mężczyzn: ich podróży, pracy i działalności społecznej, a zwłaszcza na organizowanych przez nich akcjach patriotycznych. Takie podejście 


\section{SM̂PP}

wynika w znacznej części z braku materiałów dotyczących kobiet. Nawet wśród pamiętników zbieranych w okresie międzywojennym znalazło się zaledwie kilka relacji kobiet. Inną, specyficzną barierę stwarzała być może również dominacja mężczyzn wśród badaczy problematyki emigracyjnej i polonijnej. Połączenie tych czynników ograniczały w Polsce w przeszłości priorytety polityczne. Wszystko to skutkowało brakiem wśród badaczy (ciekawe, że także wśród badaczek)² zainteresowania tematyką dotyczącą roli kobiet, zarówno w procesach migracyjnych jak i w środowiskach polskiej diaspory. Prowadziło to do ich marginalizacji, tak w syntezach, jak i w opracowaniach dotyczących różnych okresów przemieszczeń, rejonów osiedlenia czy historii polskiej diaspory. Sytuacja zaczęła się zmieniać stopniowo dopiero w ostatnim dziesięcioleciu XX w., głównie pod wpływem trendów w nauce światowej oraz publikacji dotyczących polskich emigrantek, które ukazały się za granicą ${ }^{3}$. Od tego okresu również w Polsce powstało wiele ciekawych publikacji problemowych i przyczynków na temat emigrantek ${ }^{4}$. Brakuje jednak prac syntetycznych, ukazujących dzieje emigracji z perspektywy kobiet.

Ten tekst nie aspiruje do wypełnienia tak obszernej luki badawczej. Ma jedynie zwrócić uwagę na udział kobiet w procesach migracyjnych i na konieczność uwzględniania ich roli oraz doświadczeń na obczyźnie. Przedstawi przykłady specyficznych problemów polskich emigrantek, ich przeżyć związanych z decyzją o wyjeździe, z podróżą oraz z sytuacją w nowym środowisku. Pokaże też dotyczące tej tematyki uproszczenia i schematy oraz wskaże na przemilczenia występujące w istniejących opracowaniach. Struktura tekstu jest oparta na chronologii strumieni migracyjnych, z modyfikacjami uwzględniającymi kierunki i charakter wyjazdów kobiet, a także

2 Wyjątek stanowią publikacje z badań etnograficznych i socjologicznych K. Zawistowicz-Adamskiej z roku 1948 (Społeczność wiejska. Doświadczenia i rozważania z badań terenowych w Zaborowie, Łódź) oraz K. Dudy-Dziewierz z 1939 (Wieś małopolska a emigracja amerykańska. Studium wsi Babica powiatu rzeszowskiego), Warszawa-Poznań.

${ }^{3}$ Np. E. Morawska (1985), For Bread with Batter: The Life-Worlds of East Central Europeans in Johnstown, Pennsylvania 1890-1940, New York: Cambridge University Press; M.E. Cygan (1994), Polish Women and Emigrant Husbands w: Roots of the Transplanted, vol.1: Late 19th Century East Central and Southeastern Europe, D. Hoerder, I. Blank (red.), New York; Marynia Don't Cry: Memoirs of Two PolishCanadian Families (1995), A. Kojder, B. Głogowska (red.), Toronto: Multiculural History Society of Ontario.

${ }^{4}$ Zob. np.: A. Walaszek (1998), Między tradycją a kulturą masowej konsumpcji - kobiety i kultura życia codziennego społeczności polonijnych w USA w latach dwudziestych i trzydziestych XX wieku, w: Kobieta i kultura życia codziennego wiek XIX i XX, A. Żarnowska (red.), Warszawa, s. 279-292; A. Walaszek (2002), Polskie imigrantki w miastach USA, "Przegląd Polonijny” nr 2, s. 25-41; Wkład Polek na emigracji w rozwój kultury i nauki polskiej. Materiały z sesji naukowej odbytej w Opolu 19-20 listopada 2004 roku (2004), T. Depta, D. Kisielewicz (red.), Opole: Instytut Śląski; Kobiety i procesy migracyjne (2010), A. Chlebowska, K. Sierakowska (red.), Neriton: Warszawa; Wkład Polek na emigracji w rozwój kultury i nauki polskiej. Materiały z sesji naukowej odbytej w Opolu 19-20 listopada 2004 roku (2004), T. Detyna, D. Kisielewicz (red.), Opole: Instytut Śląski; A. Maksymowicz (2015), Agnieszka Wisła i działalność Polek w Ameryce na rzecz ochotników i weteranów Błękitnej Armii, Nowy Jork-Opole: Stowarzyszenie Weteranów Armii Polskiej w Ameryce; J. Kolbuszewska (2017), Polki na uniwersytetach - trudne początki, "Sensus Historiae", nr 1, s. 35-53. 
ich pozycję i zachodzące w niej zmiany w kolejnych okresach i najważniejszych krajach osiedlenia. Podkreślane będą też podobieństwa zjawisk i procesów związanych z migracjami a odnoszących się do kobiet. Początek analizy wyznacza okres rozbiorów, kiedy po powstaniach i represjach ziemie polskie opuszczały kolejne wielkie fale emigrantów i zesłańców. Drugą granicę stanowi wybuch II wojny światowej, która przyniosła ogromne zmiany w strukturze i charakterze ruchów migracyjnych, a w ich konsekwencji znaczące przekształcenia w wielu skupiskach polskiej diaspory.

Tekst bazuje na istniejących opracowaniach dziejów polskich migracji. Wykorzystuje prace syntetyczne oraz te, które skupiają się na problematyce wyjazdów Polek oraz ich aktywności w krajach osiedlenia. Zawarte w nich analizy i wnioski są przytaczane, porównywane i poddawane krytycznej ocenie. Zestawiono też dostępne szacunki i dane statystyczne na temat udziału kobiet w ruchach migracyjnych z ziem polskich. Identyfikowane luki w opracowaniach wypełniają materiały pochodzące ze źródeł drukowanych, czyli głównie z relacji pamiętnikarskich kobiet - emigrantek. W przypadkach ich braku, lub dla wskazania procesów i zjawisk pomijanych w literaturze przedmiotu czy też podważających funkcjonujące opinie czy stereotypy, przytaczane są relacje emigrantów - mężczyzn, przy zastrzeżeniu, że są to opinie uwarunkowane odmienną perspektywą. Wykorzystanie źródeł historycznych oraz szerokiej gamy opracowań - tak o charakterze historycznym jak i zaliczanych do innych dyscyplin (np. socjologii czy etnografii) - jest zbliżone do triangulacji metodologicznej stosowanej w naukach społecznych.

Ograniczone ramy artykułu nie pozwalają niestety na uwzględnienie wszystkich wzmianek na temat kobiet, zamieszczanych w licznych pracach poświęconych różnym wycinkom i aspektom dziejów polskiej emigracji w poszczególnych krajach. Kilka przywołanych przykładów dowodzi jednak, że można tam znaleźć wiele ciekawych szczegółowych informacji.

\section{Wśród polskich zesłańców i wychodźców politycznych}

Opracowania na temat emigrantów z lat schyłku Rzeczpospolitej i pierwszych dekad po rozbiorach zupełnie nie wspominają, że były wśród nich kobiety. Niektórzy działacze polityczni, zwłaszcza magnaci, wyjeżdżali jednak z rodzinami, zatem w Wiedniu i Paryżu powstawały skupiska polskie, a w Dreźnie nawet tzw. polska kolonia5. Marginalizacja kobiet wyraźnie widoczna jest też przy rekonstrukcji dziejów popowstaniowych zsyłek w głąb Rosji. Publikacje opisujące losy skazanych wspominają, że do niektórych dobrowolnie dołączały żony i narzeczone i dzieliły ich niedolę, ale

5 Jedyny wyjątek to Genowefa z Ogińskich Brzostowska uchodząca za nieoficjalną przedstawicielkę konfederacji barskiej na dworze Wettinów. Zob. J. Kozłowski (1984), Emigracja u schyłku Rzeczpospolitej szlacheckiej i początki emigracji porozbiorowej, w: Emigracja w czasach nowożytnych i najnowszych, A. Pilch (red.), Warszawa: PWN, s. 38. 


\section{SM̂PP}

praktycznie nic więcej o nich nie wiadomo. Utrwalił się natomiast, przesiąknięty romantycznymi nastrojami epoki stereotyp, że kobiety podejmujące decyzję o dobrowolnym zesłaniu działały w przekonaniu o wypełnianiu swoich obowiązków, zarówno małżeńskich jak i patriotycznych. Legendami obrastały, opowiadane z zachowaniem poufności, tragiczne, wzruszające losy i poświęcenie Ewy Felińskiej, Apolonii Sierakowskiej, Antonilli Roszkowskiej czy Albiny z Wiszniewskich Migurskiej ${ }^{6}$. Opinie takie funkcjonowały wśród dziewiętnastowiecznych polskich elit i powtarzali je także niektórzy historycy zajmujący się epoką popowstaniową. W literaturze zwykle pomijany jest natomiast fakt, że czynnikami decydującymi o dobrowolnym zesłaniu kobiet były naciski ze strony Rosjan, konfiskata majątku skazanego, pozbawiająca jego rodzinę środków do życia oraz status prawny kobiet w zaborze rosyjskim. Oparte na źródłach publikacje na temat Polek zesłanych w głąb Rosji zaczęły pojawiać się dopiero w ostatnim dziesięcioleciu?. Dotyczą głównie Syberii. Brakuje natomiast prac dotyczących Kaukazu, gdzie trafiali zarówno zesłańcy jak i poborowi i ochotnicy robiący kariery w armii carskiej. Część tych Polaków (oficerów i podoficerów) sprowadzała żony, narzeczone a nawet osoby, z którymi zaręczali się korespondencyjnie. Informacje o takich przypadkach można odnaleźć w nielicznych zachowanych wspomnieniach zesłańców. Kreowany na tej podstawie obraz przedstawia kobiety jako „...chlubę wygnańczej gromady... [i] ozdobę płci niewieściej”"8. Jedynie wyjątkowo pojawiają się zdania, że nie wszystkie mieszkające tam Polki były typem aniołów, a "niektórym powodzenie zawróciło w głowie"9 oraz że niektóre żony podoficerów prowadziły ożywioną działalność handlową, a inne "familijne domy żołnierskie”, gdzie - jak w polskich karczmach - sprzedawano alkohol i organizowano potańcówki. Opinia ta pokazuje, że losów i postaw Polek, trafiających w głąb Rosji, nie można sprowadzać do patriotycznych schematów. Trudno jednak też generalizować na podstawie jednej relacji.

Dziewiętnastowieczne polskie wychodźstwo popowstaniowe, które dotarło na Zachód, miało charakter polityczny. Znaczną większość mężczyzn uciekających przed represjami stanowili wojskowi. Ich dzieje opisywane są głównie przez pryzmat ugrupowań politycznych oraz programów i działań na rzecz sprawy polskiej. Uwagę historyków oraz historyków literatury przyciąga także twórczość wieszczów i wybitnych

${ }^{6}$ Migurska podjęła nieudaną próbę wywiezienia męża zesłańca, wcielonego do wojska w Uralsku. W rezultacie nieudanej akcji, która nadaje się na scenariusz filmowy, cała rodzina wysłana została do Nerczyńska. Roszkowska wyjechała do Irkucka z dziećmi. Utrzymywała rodzinę udzielając lekcji francuskiego, wspierała katorżników, a stworzony przez nią dom był przez wiele lat ośrodkiem życia towarzyskiego polskich zesłańców. Zob. B. Jędrychowska (2014), Żony XIX-wiecznych zesłańców jako organizatorki życia rodzinnego na Syberii, "Wychowanie w Rodzinie” t. IX, nr 1, s. 164.

7 Zob. M. Cwenk (2012), Felińska, Lublin: KUL; A. Sierakowska z Dalewskich (2010), Wspomnienia, J. Sikora-Kulesza, T Bariaškaitè (red.), Warszawa: Neriton; A. Markiewicz (2018), Kobiety i rodziny powstańców styczniowych zesłanych w głąb Rosji, Warszawa: Difin.

${ }^{8}$ M. Gralewski, Kaukaz. Wspomnienia z dwudziestoletniej niewoli. Opisanie kraju. Ludność. Zwyczaje i obyczaje, Lwów 1877 za: B. Baranwski, K. Baranowski (1985), Polaków kaukaskie drogi, Łódź: KAW, s. 56.

9 Tamże, s. 57. 
artystów Wielkiej Emigracji. Mniej eksponowana i stosunkowo mało znana jest rola charytatywno-opiekuńczego Towarzystwa Dobroczynności Dam Polskich, założonego w Paryżu w 1834 r. przez księżną Annę Czartoryską (i działającego do I wojny światowej), czy funkcjonującego w latach 1844-1870 Instytutu Panien Polskich. Ten ostatni kształcił każdego roku na guwernantki i nauczycielki około 40 dziewcząt (głównie córki emigrantów). Rzadko też przypominane są postacie księżnej Anny, jej matki Anny Sapieżyny zarządzającej finansami Hotelu Lambert, czy powieściopisarki i tłumaczki Klementyny z Tańskich Hoffmanowej propagującej niezależność ekonomiczną kobiet. Niewiele wiadomo o - analogicznej jak w wypadku zesłańców - praktyce sprowadzaniu z Kraju żon dla polistopadowych emigrantów, choć znany jest choćby przykład Celiny Mickiewiczowej. O szarytkach (zakonnicach ze Zgromadzenia Sióstr Miłosierdzia), które od 1846 roku prowadziły w Paryżu Zakład Św. Kazimierza, a w nim sierociniec i dom opieki dla weteranów, wspomina się głównie ze względu na to, że jednym z pensjonariuszy był Cyprian Kamil Norwid ${ }^{10}$.

\section{Po wiedzę}

Odrębnym zagadnieniem, ciekawym i czekającym na opracowanie, są wyjazdy studentek i badaczek na zagraniczne uniwersytety. Brak możliwości zdobywania wiedzy na ziemiach polskich ${ }^{11}$, przykład studiujących mężczyzn oraz wpływy zachodnioeuropejskich ruchów emancypacyjnych kobiet, ośmieliły Polki do kształcenia się poza granicami państw zaborczych. Pionierkami były nauczycielki oraz niezależne Polki pragnące poszerzyć swoją wiedzę, walczące z trudnościami i wyłamujące się ze stereotypowych ról społecznych. Podejmowały one studia w Szwajcarii ${ }^{12}$, we Francji, w Belgii, w Niemczech. Polki studiowały medycynę, nauki ścisłe i przyrodnicze, ale także historię i nauki społeczne. Zestawienie pełnej listy wydaje się niemożliwe. Znana i opisana jest kariera Marii Skłodowskiej-Curie. Ostatnio przypominane są też dokonania antropolożki i badaczki ludów syberyjskiej Marii Czaplickiej ${ }^{13}$. Właściwie zapomniana została natomiast Gabriela Balicka-Iwanowska, która w Genewie ukończyła studia z botaniki doktoratem, prowadziła badania w Monachium, a w 1919 r. została

10 S. Kalembka (1971), Wielka Emigracja. Polskie Wychodźstwo Polityczne w latach 1831-1862, Warszawa: Książka i Wiedza, s. 305.

11 W Galicji prawo dopuściło kobiety na uniwersytety dopiero w roku 1897 i to ze znacznymi ograniczeniami. Zob. J. Kolbuszewska (2017), Polki na uniwersytetach... s. 48.

12 W Zurychu pierwsza Polka, Stefania Walicka, rozpoczęła naukę w roku 1870 i zakończyła studia doktoratem pięć lat później; tamże, s. 43. W latach 1910-1912 na uniwersytecie w Genewie było 265 polskich studentek i - ze względu na pobór do wojska - tylko 140 studentów. Zob. J.A. Konopka (2010), Polacy na uniwersytecie w Genewie i Polonica biblioteki uniwersyteckiej (lata 1817-1917) http://skryba. inib.uj.edu.pl/goscie/JAK/2010/JAK-2010.pdf [dostęp: 6.07.2019].

13 M. Banaszkiewicz (2017), Antropolog wobec odmienności kulturowej i przyrodniczej. Refleksje Marii Czaplickiej z ekspedycji na Syberię, "Studia Etnologiczne i Antropologiczne” nr 17, s. 32-46; G. Kubica-Heller (2015), Maria Czaplicka - płeć, szamanizm, rasa: biografia antropologiczna, Kraków: WUJ. 


\section{SM̂PP}

posłanką na Sejm Rzeczpospolitej. Fakt, że Zofia Stryjeńska w 1911 r. podjęła studia w Monachium, podając się za mężczyznę, jest najczęściej pomijany w jej biografiach ${ }^{14}$. Polskie artystki, podobnie jak i artystów, przyciągał przede wszystkim Paryż. Według ankiety przeprowadzonej przez Wacława Gąsiorowskiego w roku 1913 było tam aż 68 polskich malarek i 10 polskich rzeźbiarek, wśród nich także emancypantki, feministki i osoby sympatyzujące $z$ ruchem socjalistycznym ${ }^{15}$. W okresie międzywojennym kobiety uzyskały dostęp do uniwersytetów w Polsce, ale młodzi ludzie (także kobiety) ciągle korzystali z możliwości studiowania za granicą. Jest to jednak problematyka zupełnie nieopracowana. Dla stworzenia pełnego obrazu zagranicznych studiów oraz karier naukowych i artystycznych kobiet potrzeba jeszcze wielu szczegółowych i żmudnych analiz.

\section{Wśród emigrantów sezonowych w krajach niemieckojęzycznych}

Większość opracowań na temat dziejów emigracji ekonomicznej z ziem polskich, podobnie jak w przypadku emigracji politycznej, bazuje na doświadczeniach mężczyzn i skupia się głównie na ich problemach. Oni byli pionierami wyjazdów. Od ostatnich dekad XIX w. robotnicy polscy znajdowali pracę najpierw sezonową, później także stałą, głównie na terenach najbliżej położonych krajów niemieckojęzycznych. W ślad za nimi, czasem rekrutowane przez agentów, podążały kobiety. Ich status był zróżnicowany i zależał od rodzaju podejmowanej pracy oraz miejsca osiedlenia. W rejonie wschodnich i środkowych Niemiec Polki podejmowały głównie sezonowe prace rolne $w$ wielkich majątkach ziemskich ${ }^{16}$, ale pracowały też np. w cegielniach. Nie ma ich relacji, ale wzmianki o obu tych grupach (o "landsmankach") pojawiają się we wspomnieniach Jakuba Wojciechowskiego. Według relacji tego autora polskie pracownice, podobnie jak mężczyźni, mieszkały w barakach (tzw. "kosiarach”). Wojciechowski oceniał "kosiary" kobiece jako gorsze i twierdził, że w tych przy cegielni były "żywe robaczki" ${ }^{17}$, ale sytuację w jednym z "kosiarów" wiejskich opisał jako dramatyczną: „... gdy zem tam zased, to zem się też zląk, bo te dziewczyny, to ani łóżków nie miały, jeno jak bydło na podłodze spały"18. Wspomnienia Wojciechowskiego zawierają także wiele innych ciekawych uwag odnoszących się do polskich emigrantek. Twierdził, że młodsze z nich i biedniejsze miały tylko męskie ubrania, ale

14 Ś. Lenartowicz (2012), Podróże Zofii Stryjeńskiej i ich paryskie etapy, „Archiwum Emigracji. Studia Szkice - Dokumenty", nr 1-2, s. 102.

15 E. Bobrowska (2012), Emancypantki? Artystki polskie w Paryżu na przełomie XIX i XX W. „Archiwum Emigracji. Studia - Szkice - Dokumenty", nr 1-2, s. 11.

16 Zob. J. Kozłowski (1992), Polacy w Niemczech w XIX u XX w., w: Polonia w Europie, B. Szydłowska-Ceglowa (red.), Poznań: Zakład Badań Narodowościowych PAN, s. 221-243.

17 J. Wojciechowski (1971), Życiorys własny robotnika, t. 1, Poznań: Wydawnictwo Poznańskie, s. 206.

18 Tamże, s. 237. 
starsze na tańce ubierały się już w stroje miejskie i bywały na niemieckich zabawach ${ }^{19}$, co stwarzało im możliwość wyjścia poza polskie środowisko. Wojciechowski wymienia zarówno przykłady dziewcząt, które ze wszystkich swoich problemów zwierzały się księdzu jak i takich, które z chłopakami „do krzoków chodziły”20. Z męskiej perspektywy opisał też rywalizację o dziewczyny oraz zaręczyny i wesela organizowane w "kosiarach", zwykle bez udziału rodziców nowożeńców. W przywoływanym pamiętniku można znaleźć wzmianki zarówno o pozostawionych w Kraju i zdradzanych żonach, o mężach przepijających wszystkie zarobione pieniądze jak i o polskich prostytutkach oraz o gospodyniach sypiających z sublokatorami. Przywołane przykłady pokazują więc całą mozaikę losów i postaw polskich emigrantek oraz wywoływanych czy warunkowanych emigracją zmian tradycji i obyczajów.

\section{W Zagłębiu Ruhry}

Zjednoczenie Niemiec uruchomiło falę wewnętrznych migracji do kopalń i hut Westfalii i Nadrenii. Wciągnęła ona również Polaków. Badacze podają, że w 1907 r. stanowili tam ponad 93\% wśród zawodowo czynnych imigrantów ${ }^{21}$. Ten specyficzny ruch ma bogatą literaturę. Obejmuje ona również analizy ukazujące pozycję kobiet zarówno wśród migrantów jak i w diasporze powstałej w wyniku tej migracji. Początkowo, podobnie jak w wypadku innych migracji sezonowych, do Zagłębia Ruhry przyjeżdżali przede wszystkim mężczyźni. Część z nich zamieniała jednak pobyt czasowy na stały i w związku z tym w skupiskach polskich, powstających przy zakładach przemysłowych, stopniowo rosła liczba kobiet. Ze statystyk niemieckich wynika, że w 1912 r. w trzech rejencjach położonych nad Renem żyło ponad 63 tysiące Polek w wieku powyżej 14. roku życia. Zdecydowana większość z nich (prawie 57 tys.) została sklasyfikowana jako „żony i córki pozostających w gospodarstwach domowych mężów i ojców", a kilkanaście procent stanowiły wdowy oraz osoby pracujące jako służące ${ }^{22}$. Niski odsetek kobiet samotnych interpretowany jest jako skutek dysproporcji między liczbą mężczyzn i kobiet, a w konsekwencji łatwym znajdowaniem partnerów przez te ostatnie ${ }^{23}$. Na początku XX w. odsetek czynnych zawodowo polskich kobiet był w Zagłębiu Ruhry stosunkowo wysoki, bo wynosił około 30\%. Jan Molenda udowodnił, że żadnej pracy nie podejmowały tam jedynie żony dobrze zarabiających mężów. Oszacował też, że około 30\% pracujących Polek było zatrudnionych w rolnictwie (prawdopodobnie sezonowo), a jedynie 3\% w przemyśle

\footnotetext{
19 Tamże, s. 195-196, 303.

20 Tamże, s. 216.

21 J. Kozłowski (1992), s. 226.

22 Tamże, s. 120.

23 J. Molenda (1997), Miejsce kobiet wśród polskiego wychodźstwa w reńsko-westfalskim okręgu
} 


\section{SM̂PP}

(głównie odzieżowym i tekstylnym). Relatywnie duża grupa żon oraz córek polskich górników i robotników prowadziła natomiast małe sklepiki spożywcze lub kramy z wyrobami rzemieślniczymi, zakładane dzięki rodzinnym oszczędnościom² ${ }^{24}$. Możliwość uzyskania dochodów, rozszerzenia kontaktów, a w pewnym sensie także podniesienia prestiżu w lokalnej polskiej społeczności dawało również "trzymanie stołowników", czyli sublokatorów. Nazywano tak mężczyzn pracujących przeważnie sezonowo, zarówno kawalerów jak i tych, którzy na emigracji przebywali bez rodzin. Nie ma danych na temat liczby Polek zarabiających w ten sposób, ale ze statystyk wynika, że na przykład w 1910 r. Polaków - „stołowników” było aż 35 tysięcy. Przykłady opisane we wspomnieniach Jakuba Wojciechowskiego świadczą, że o doborze "stołowników" generalnie decydowała głowa rodziny, czyli mąż. Zaradne mężatki potrafiły jednak zdobyć silną pozycję w rodzinie i wśród sąsiadek. Zwykle status kobiet wyznaczały jednak warunki materialne bazujące na zarobkach pracujących mężczyzn. Dochody żon i córek stanowiły jedynie uzupełnienie domowych budżetów ${ }^{25}$, choć kobiety wnosiły do niego znaczący wkład. Dla części z nich był to też początek emancypacji zawodowej.

W polskich skupiskach funkcjonujących na terenie Zagłębia Ruhry istniała wyraźna presja społeczna na wypełnianie przez kobiety tradycyjnych ról, zgodnych z kanonem kulturowym przywiezionym z ziem polskich. Według stereotypu funkcjonującego zarówno na emigracji jak i w opisującej ją literaturze, Polki miały być domowymi strażniczkami polskości, przeciwstawiającymi się germanizacji oraz zabiegającymi o utrzymanie języka polskiego oraz przywiązania swych dzieci do polskości i wiary katolickiej. Jan Molenda zderzył ten stereotyp z informacjami zawartymi w sprawozdaniach niemieckiej policji oraz w artykułach polskojęzycznej prasy. Dowiódł, że ograniczeniu aktywności kobiet poza domem (nie tylko Polek) sprzyjało ustawodawstwo niemieckie. Do 1908 r. zakazywało im ono udziału w organizacjach o charakterze społeczno-narodowym. Kobiety mogły wstępować jedynie do organizacji religijnych związanych z Kościołami. W konsekwencji przy katolickich parafiach funkcjonowały liczne bractwa różańcowe i stowarzyszenia o charakterze religijnym i samopomocowym. Przyciągały one wiele polskich imigrantek. Pod wpływem kontaktów z kobietami niemieckimi, ale również celowych akcji germanizacyjnych prowadzonych przez niektórych niemieckich duchownych, część Polek akceptowała opinie o wyższości niemieckiej kultury i o konieczności wprowadzania jej w rodzinach polskich imigrantów. przenosiła do własnych rodzin przekonanie o wyższości niemieckiej kultury i konieczności jej przyjmowania. Za popieranie akulturacji i integracji ze społeczeństwem niemieckim niektóre z nich były ostro krytykowane przez polskie stowarzyszenia narodowe. Historycy przytaczają co prawda dowody na to, że część polskich filii Bractwa Różańcowego i Związku Św. Elżbiety wyłamywało się spod wpływów niemieckiego

\footnotetext{
24 J. Kozłowski (1992), s. 226.

25 J. Molenda (1997), s. 123.
} 
kleru i podejmowało działalność wspierającą interesy grupy polskiej. Nie zmienia to jednak faktu, że - jak przypomina Molenda - pierwsze polskie kobiece organizacje o charakterze świeckim powstały w Zagłębiu Ruhry dopiero w 1908 r. Ich szybki rozwój nastąpił bezpośrednio przed pierwszą wojną światową, po zadeklarowaniu w 1913 r. na Kongresie Polaków w Winterswijk równych praw kobiet i mężczyzn do wstępowania do polonijnych organizacji. Takiej równości ewidentnie wcześniej nie było. Zmiana nastawienia polonijnych działaczy do aktywności kobiet sprawiła, że w 1914 r. w Zagłębiu Ruhry funkcjonowało już 80 polskich organizacji kobiecych oraz Związek Polskich Kobiet jako ich centrala ${ }^{26}$. Działalność w ramach tych struktur, podobnie jak i poparcie Polek dla strajków górniczych w czasie I wojny światowej, wymagają jednak dalszych badań.

\section{W Danii i we Francji przed rokiem 1914}

Obok Niemiec innym europejskim krajem, do którego przed I wojną światową trafiło kilka tysięcy polskich emigrantek, była Dania. Ten ruch, który początkowo miał głównie charakter sezonowy, nazywany jest „emigracją buraczaną”. Zainicjowali go w 1893 r. agenci rekrutujący pracowników na plantacje buraków cukrowych i do cukrowni. Większość wyjeżdzających (w 1911 r. aż 80\% z 11 tys.) stanowiły młode kobiety pochodzące głównie Zachodniej Galicjil27. Otrzymywały one wynagrodzenie niższe niż Duńczycy, ale wyższe niż za podobne prace w Niemczech. Inaczej niż we Francji, a podobnie jak w Niemczech, stawki za pracę kobiet - imigrantek były takie jak chłopców poniżej 18. roku życia ${ }^{28}$. Polskie imigrantki nie znały miejscowego języka i nie miały okazji się go uczyć. Pracowały w polu od 5 rano do 7 wieczorem, niezależnie od pogody. Mieszkały zwykle w barakach z dużymi wspólnymi salami, albo w zabudowaniach gospodarczych, a nawet na strychach. Rodziny imigrantów, nawet wielodzietne, egzystowały w jednej izbie z kuchnią i komórką. W najtrudniejszych warunkach znajdowały się osoby pracujące na wielkich farmach kontrolowanych przez nadzorców. Presja wpływowych osobistości oraz opinii publicznej doprowadziła w 1908 r. do przyjęcia w Danii Ustawy o Polakach (Polakloven), która ograniczyła uprawnienia nadzorców i zabezpieczyła status prawny imigrantów ${ }^{29}$. Jedynie część polskich robotnic wracała z Danii na zimę do domu. Pozostałe zwykle

26 J. Molenda (1997), s. 126-132; D. Skrabania, "Ruhrpolen" - Polacy z Zagtębia Ruhry, Porta Polonica https://www.porta-polonica.de/pl/atlas-miejsc-pami\%C4\%99ci/ruhrpolen-polacy-z-zaglebia-ruhry [data dostępu: 25.06.2019].

27 S. Kościelecka (1983), Dzieje Polonii w Danii w latach 1892-1940, Szczecin: WSP, s. 54-57.

28 M.A. Kowalski (1970), Polacy w Danii, „Etnografia Polska”. T. XIV, z.1, s. 59; S. Kościelecka, Dzieje Polonii..., s. 76.

${ }^{29}$ E. Later-Chodyłowa (1992), Polonia w krajach skandynawskich - Dania, w: Polonia w Europie, B. Szydłowska-Ceglowa (red.), Poznań: Zakład Badań Narodowościowych PAN. 


\section{SM̂PP}

zmieniały pracę lub przenosiły się do miast. Część osiedlała się na stałe i zakładała rodziny. Małżeństwa z protestanckimi Duńczykami nie należały do rzadkości, choć wymagały dyspensy biskupa. Udzielano ich rocznie $100-150^{30}$. W publikacjach na temat „emigracji buraczanej” powtarzają się zdania o mocnym przywiązaniu emigrantek do Kościoła katolickiego i praktyk religijnych oraz o znaczeniu fali polskiej emigracji dla odrodzenia się katolicyzmu w Danii. Z drugiej strony, można wyłowić informacje o problemach: pijaństwie, "niedomogach życia rodzinnego”, dziewczętach "schodzących na złą drogę", o nieślubnych dzieciach (początkowo matki takich dzieci wydalano z Danii), ślubach zawieranych "na ratuszu” (ślub cywilny był dla Polek ewidentnie nowością wybieraną raczej wyjątkowo) oraz o duńskim powiedzeniu "żyć po polsku”, czyli bez jakiejkolwiek legalizacji związku¹. Ostania z wymienionych sytuacji była zwykle wynikiem braku dokumentów umożliwiających zawarcie formalnego małżeństwa. Emigrację do Danii oraz powroty zatrzymała I wojna światowa, ale w latach 20. XX w. ruch ten był kontynuowany. W ramach akcji zwalczania handlu kobietami podniesiono jednak wówczas do lat 21 barierę wieku dla kobiet, które mogły otrzymać paszport emigracyjny ${ }^{32}$. Warto odnotować, że w kilku publikacjach poświęconych polskiej emigracji oraz Polonii w Danii, nawet w tych napisanych przez kobiety, mimo zamieszczenia informacji o strukturze tego strumienia emigracji, konsekwentnie używane są ogólne terminy: „polscy robotnicy sezonowi” i "polscy robotnicy rolni”. Wkład Polek w gospodarkę Danii docenili natomiast mieszkańcy tego kraju wystawiając im w 1940 r. pomnik w miasteczku Saksøbing na wyspie Lolland ${ }^{33}$.

Od 1908 r. emigranci z ziem polskich, zaczęli się kierować również do Francji. Pochodzili oni głównie z Galicji i przylegających do granicy Austro-Węgier terenów Królestwa Polskiego. Z założenia byli to robotnicy sezonowi, którzy podejmowali pracę zarówno na roli, jak i w przemyśle. Część z nich przedłużała pobyt, inni wyjeżdżali kilkakrotnie, a niektórzy zmieniali charakter zajęć i zostawali. Badacze szacują, że do roku 1913 ruch ten mógł objąć łącznie nawet 20000 osób, w tym około $20 \%$ stanowiły kobiety, zwykle żony oraz krewne ${ }^{34}$. O charakterze i warunkach pracy tych kobiet wiadomo niestety niewiele. Emigrantki pracowały głównie w rolnictwie, a w miastach na przykład w kuchniach, szwalniach czy warsztatach rzemieślniczych, choć można też znaleźć relacje świadczące o tym, że na budowach „woziły taczki z gliną". Warto podkreślić, że status oraz wynagrodzenie polskich imigrantów były niższe niż pracowników francuskich, a nawet pracujących wówczas we Francji

30 W. Zdunek (1982), Duszpasterstwo Polaków w Danii (1893-1978),"Studia Polonijne" nr 5, s. 163.

31 Tamże, s. 158.

32 M.A. Kościelecka (1983), s. 57.

33 Pomnik "Buraczanych dziewcząt” ma 75 lat, Federacja Polonia, http://www.federacja-polonia.dk/ news-pomnik-buraczanych-dziewczat-ma-75-lat, 108.html, [data dostępu: 20.06.209].

${ }_{34}$ M. Gmurczyk-Wrońska (1996), Polacy we Francji w latach 1871-1914. Społeczność polska i jej podstawy materialne, Warszawa: Neriton, s. 240-241. 
imigrantów pochodzących z innych krajów. Zarobki Polek - niezależnie od wykonywanych zajęć - były jeszcze niższe ${ }^{35}$. W praktyce zarówno migracje do Danii jak i do Francji stanowiły wstępne fazy ruchów, które rozwinęły się po I wojnie światowej.

\section{Za ocean na własne gospodarstwo}

W ramach masowej emigracji zarobkowej Polki wyjeżdżały do Ameryki Północnej oraz do Ameryki Południowej. W USA pionierami z ziem polskich byli Ślązacy. Ich pierwsza grupa, która dotarła do Teksasu w 1854 r., składała się ze 150 rodzin. W kolejnych latach napłynęły następne rodziny ze Śląska, łącznie około 2300 osób. Musiał być wśród nich duży odsetek kobiet, ale informacje o nich mają jedynie wymiar ciekawostek: a mianowicie, że w czasie długiej podróży rodziły się dzieci oraz że miejscowi Teksańczycy traktowali Ślązaczki nieprzyjaźnie, bo miały spódnice do połowy łydki, co uznawano za nieprzyzwoite. O doświadczeniach pionierek nie ma żadnych wzmianek. Podobnie jak i o innych kobietach, które z ziem polskich przyjechały do USA przed rokiem 1860. Fala polskiej emigracji, która osiedlała się na roli i w różnych stanach stworzyła około 20 osad, szacowana jest na co najmniej 30 tysięcy. Jest ona jednak bardzo słabo udokumentowana ${ }^{36}$. Podobnie wygląda też historia Kaszubów, którzy uchodzą za pionierów polskiego osadnictwa na ziemiach kanadyjskich. Pierwszymi osadnikami było tam kilkunastu mężczyzn, którzy w 1858 r. objęli działki przy drodze na północny zachód od Ottawy. W ciągu następnych lat dołączały do nich rodziny. W 1860 r. rejestry odnotowały już 22 rodziny kaszubskie, trzy lata później 44, a w 1886 roku 195. Od 1858 r. na listach osadników wymieniane były ich żony, z imieniem i nazwiskiem panieńskim. Samotni mężczyźni należeli do wyjątków ${ }^{37}$. Rejestry nowych osadników oraz napisy nagrobne na starych kaszubskich cmentarzach w rejonie Barry's Bay i Wilna w prowincji Ontario to jedyne ślady po imigrantkach przybyłych z okolic Bytowa i Kościerzyny.

Informacji na temat kobiet towarzyszących polskim pionierom, którzy od 1875 r. docierali do stanu Santa Catarina w Brazylii, jest jeszcze mniej. Szacunki podają, że do tego kraju do I wojny światowej przybyło 100 tys. Polaków, a do 1939 r. jeszcze ponad 40 tys. W okresie międzywojennym do Argentyny trafiło 157 tys. obywateli

${ }^{35}$ Z zachowanych, wycinkowych materiałów krakowskiego Biura Pośrednictwa Pracy, odnoszących się do roku 1909 wynika, że miesięczne zarobki kobiet emigrantek wynosiły 38 franków, a mężczyzn 42 franków. Roczne wynagrodzenie kobiet było niższe nawet od wynagrodzenia młodych mężczyzn (odpowiednio 360 franków i 450 franków); tamże, s. 229.

${ }^{36}$ A. Brożek (1972), Ślązacy w Teksasie: Opole Instytut Śląski; J.S. Pula, Polska Diaspora w Stanach Zjednoczonych Ameryki do roku 1914, w: Polska diaspora, A. Walaszek (red.), Kraków: Wydawnictwo Literackie, s. 58-59.

${ }^{37}$ W 1872 r. zarejestrowano natomiast niejakiego Paula Muszkę i jego 5 córek. Zob. J.C. Blank (2016), Creating Kashubia. History, Memory and Identity in Canada's First Polish Community, Montreal: McGill, s. 253-256. 


\section{SM̂PP}

polskich (Polaków, Ukraińców, Żydów). W obu przypadkach była to w większości emigracja rodzin, które osiedlano na działkach wyznaczanych w puszczy, gdzie w czasie upałów, w prowizorycznych szałasach, walcząc z insektami, gadami i gryzoniami musieli przeżyć pierwsze miesiące ${ }^{38}$. Tematyka kobiet emigrantek nie pojawia się jednak w źródłach ani w opracowaniach na temat tych osadników. W opublikowanym w 1939 r. tomie wspomnień emigrantów żyjących w Ameryce Południowej nie ma ani jednego tekstu napisanego przez kobietę, a nawet we wspomnieniach mężczyzn wzmianki o matkach, żonach i córkach pojawiają się niezwykle rzadko ${ }^{39}$. Większość polskich rodzin żyła tam w rejonach odległych od miast, według wzorów przywiezionych ze Starego Kraju. Tak w Brazylii jak i w Argentynie zmiany pozycji kobiet, hamowane były dodatkowo przez otoczenie społeczne, w którym panował kult silnych mężczyzn.

Pewnych analogii można się dopatrzyć porównując sytuację polskich pionierek w Ameryce Południowej i na kanadyjskich preriach. Tam od lat 80. XIX w. kierowano imigrantów, w tym przybyszy z ziem polskich. Tak jak w Brazylii czy Argentynie osadnicy trafiali na działki do wykarczowania, położone daleko od większych osad. W odniesieniu do Kanady jest jednak nieco więcej źródeł historycznych. Wynika z nich, że często mężczyzna wyjeżdżał pierwszy i za zarobione pieniądze opłacał przyjazd rodziny oraz zadatek na wybraną przez siebie działkę. Żona (czasem z dziećmi) musiała samodzielnie odbyć nie tylko kilkunastodniową podróż przez ocean, ale później jeszcze w ciągu kilku dni przemierzyć pociągiem pół kontynentu. U celu czekała na nią zwykle półziemianka lub kabina z pni drzew. Konstrukcje te szokowały z pewnością nawet kobiety przyjeżdzające $z$ bardzo biednych polskich wsi. W takich warunkach rodzina, często z dziećmi, przeżywała surową kanadyjską zimę i następujące po niej roztopy. Latem plagą były komary, a zimą poszukujące pożywienia niedźwiedzie, które wywoływały paniczny strach i niszczyły z trudem budowane gospodarstwo. Dodatkowo - inaczej niż w Ameryce Południowej - kobiety przez długi okres zostawały w takich warunkach same lub z dziećmi, gdy mąż zarabiał na niezbędne inwestycje przy robotach kolejowych, wyrębie lasu czy w gospodarstwach sąsiadów ${ }^{40}$. Jednym z trudniejszych problemów osadniczek okazywał się brak butów, uniemożliwiający im wyjście z domu w czasie wielkich śniegów. W pamiętnikach są dowody, że niektóre z nich, w lecie chodziły boso po lesie ${ }^{41}$. Nawet w kilka lat po zagospodarowaniu, mimo obowiązku szkolnego, dzieci osadników (córki częściej niż synowie) nie zawsze uczęszczały do szkoły, gdyż była zbyt daleko. Warto zwrócić uwagę, że wychowane

${ }^{38}$ K. Smolana (1983), Za ocean po lepsze życie, w: Dzieje Polonii w Ameryce Łacińskiej, Wrocław: Ossolineum, s. 40-55.

${ }^{39}$ Pamiętnik nr 8 (s. 78-79), Pamiętnik nr 10 (s. 131), Pamiętnik n. 16 (s. 276, 281), w: Pamiętniki emigrantów. Ameryka Łacińska (1939), Warszawa: IGS.

${ }^{40}$ M.A. Jarochowska (2006), Poza gniazdem. Wizerunek polskiej emigrantki w Kanadzie w XX wieku, Montreal: Polski Instytut Naukowy w Kanadzie, s. 65-74.

${ }^{41}$ R. Dul, The Woźny Family, w: Polish Setlers..., s. 211-212. 
na preriach córki osadników były cenione jako kandydatki na żony imigrantów kawalerów. Wspomnienia mężczyzn dowodzą, że pozycja żon była w takich związkach mocniejsza. Mężowie słuchali ich rad, liczyli się z ich opiniami, wspólnie z nimi podejmowali najważniejsze decyzje. Te partnerskie relacje wynikały głównie z tego, że takie żony przynajmniej trochę znały język i sposób życia na kanadyjskich preriach. Jeszcze w okresie międzywojennym zdarzało się jednak, że ojciec oddawał nastolatkę na służbę do farmera w sąsiedztwie i odbierał zarobione przez nią pieniądze lub przymuszał do małżeństwa z sąsiadem. Opisano przypadki, że niemal niewolnicza praca ponad siły oraz izolacja wynikająca z piętrzących się trudności i nieznajomości języka, skutkowały chorobami lub załamaniem psychicznym, a nawet śmiercią kobiety. Bywały przypadki, że zdesperowane kobiety próbowały, z różnym skutkiem, uciec tak od niechcianych pracodawców jak i od własnej rodziny. Niektórym - zwłaszcza w czasie kryzysu lat 30. - udawało się przekonać męża do przeniesienia się do miasta ${ }^{42}$. Znaczna część polskich pionierek potrafiła jednak przetrwać trudne warunki i dzięki ogromnemu wysiłkowi całej rodziny zagospodarować, utrzymać, a nawet powiększyć farmę. Losy takich kobiet nie znalazły jednak odbicia w źródłach.

Odrębną grupę Polek emigrujących do Kanady, głównie w latach 20. XX w., stanowiły niezamężne kobiety sprowadzane do pracy w charakterze służby domowej. Podpisywały one dwu lub trzyletnie kontrakty i większość z nich trafiała na farmy. Według kilku zachowanych relacji część z nich, już w czasie podróży przez Kanadę, próbowała pozostać w którymś z dużych miast. Udawało się to jednak nielicznym, gdyż transporty były nadzorowane ${ }^{43}$. Niektóre z dziewcząt uciekały też od nadmiernie wymagających pracodawców. Miały szczęście jeśli spotkały wówczas życzliwych ludzi, którzy kierowali je do instytucji pomocowych (np. Salvation Army) lub do polskich duchownych. Dzięki temu znajdowały nowe miejsca pracy. Po niektórych ginął jednak ślad. Część emigrantek dotrzymywała jednak warunków umowy o pracę, a nawet znajdowała mężów i zostawała na preriach. Większość po zakończeniu kilkuletnich kontraktów, przenosiła się do miast. Kobiety te zwykle znały już podstawy języka i przynajmniej częściowo - kanadyjskie realia. Przeważnie jednak dołączały do lokalnej społeczności polonijnej.

\section{Polskie imigrantki w amerykańskich miastach}

Emigranci ekonomiczni kierujący się do USA od lat 70. XIX w. trafiali do miast i ośrodków przemysłowych. Była to głównie ludność chłopska. Dominowali młodzi, samotni mężczyźni planujący powrót z zarobionymi oszczędnościami lub zakup ziemi w Ameryce. Realia amerykańskie zmieniały jednak większość tych planów. Wielu sprowadzało bliższych i dalszych krewnych, a także znajomych i pozostawało w amerykańskich

42 A. Puzianowski, Experience of a Domestic and a Miner's Wife w: Polish Setlers..., s. 151-153.

${ }^{43}$ Carolina Dziurzyński's Story, w: Polish Setlers..., s. 84-85. 


\section{SM̂PP}

miastach. W szacowanej na przełomie XIX i XX w. na 1,5 miliona osób fali szybko zwiększała się liczba kobiet, dochodząc przed I wojną do 30\%, a według niektórych badaczy nawet do $40 \%{ }^{44}$. Motywy emigracji kobiet są nadal przedmiotem dyskusji specjalistów, ale statystyki dowodzą, że ich procentowy udział w ruchu powrotnym był znacznie niższy niż wśród przyjeżdżających. Adam Walaszek ciekawie przedstawia pierwsze doświadczenia polskich emigrantek w amerykańskich miastach, ich zaskoczenia i rozczarowania. Pisze też o pierwszych decyzjach: wyborze pracy oraz męża. Autor dostrzega nadzór rodziny i przyjaciół nad decyzjami młodych kobiet, ale podkreśla że w Ameryce istniała większa swoboda wyboru partnera, że emigranci wyeliminowali tradycję posagu oraz, że to narzeczony pokrywał koszty ceremonii, ślubnej wyprawy i wyposażenia mieszkania nowożeńców ${ }^{45}$. Przywoływana publikacja nie wspomina jednak o aranżowaniu małżeństw na odległość i sprowadzaniu żon na zamówienie, co do pewnego stopnia było powielaniem opisanych wcześniej praktyk zesłańców i wychodźców politycznych. Podobnie jak tam, również w Ameryce zdarzało się, że małżeństwa zawierały osoby mało sobie znane, a nawet zupełnie się nieznające. Z zachowanych źródeł wynika, że aranżowanych przez ocean małżeństw było wiele. M.A. Knothe twierdzi nawet, że Polacy przenieśli do Ameryki instytucję swatki i że zyskało to nawet wymiar komercyjny. Sprowadzana panna była przez trudniących się tym procederem „zmieniana na Amerykankę": kupowano jej amerykańskie ubrania, bieliznę i buty. Koszty, z procentem, pokrywał znaleziony mąż ${ }^{46}$. Brakuje niestety informacji o tym na ile były to szczęśliwe związki. To, że zdarzały się też nieudane, a nawet prowadzące do życiowych dramatów, świadczą wspomnienia imigrantki z New Castle w Pensylwanii. Została ona sprowadzona przez kuzyna i po 3 tygodniach, w pośpiechu, wydana za mąż za człowieka, który jak się dowiedziała - opłacił jej bilet. Mimo próby protestu, wstrętu do kandydata na męża, a nawet pytań ze strony księdza udzielającego ślubu, nie odważyła się na sprzeciw. Presja krewnych oraz wydatki poniesione przez kandydata na męża praktycznie wymusiły ślub i sprowadziły go do transakcji, która przyniosła kobiecie serię dalszych nieszczęśćc ${ }^{47}$. Pamiętniki dostarczają jednak także przykładów świadczących o tym, że samodzielny wybór życiowych partnerów także nie zawsze był szczęśliwy. Z zachowanych listów wynika, że zarówno rodziny w Kraju jak i krewni w Ameryce starali się wpływać na decyzje żyjących na emigracji kobiet, zwłaszcza młodych. Świadczą o tym rady przekazywane $w$ listach i prośby aby potencjalny kandydat pochodził przynajmniej z tej samej parafii co dziewczyna.

44 J. Pula (2001), Polska diaspora w Stanach Zjednoczonych do 1914 roku, w: Polska diaspora..., s. 65; A. Walaszek (2002), s. 25-26.

45 A. Walaszek (2002), s. 28-29.

${ }^{46}$ M.A. Knothe (1997), Recent Arrivals: Polish Immigrant Women's Response to the City, w: Peasant Maids - City Women. From the European Countryside to Urban America, Ch. Harzig (red.), Ithaca and London: Cornell University Press, s. 314.

47 Pamiętnik nr 26, w: Pamiętniki emigrantów. Stany Zjednoczone (1977) t. 1, Warszawa: Książka i Wiedza, s. 74. 
Przeważnie ślub zawierano w Kościele katolickim, choć zdarzały się odstępstwa wynikające z różnego rodzaju przeszkód. Ponowne związki legalizowano niekiedy w innym Kościele (np. narodowym lub jednym z protestanckich). Zdarzały się też, wspominane głównie w pamiętnikach mężczyzn, przypadki bigamii, gdy prawowita żona zostawała w Kraju. Podobnie jak wśród polskich emigrantów w Danii zawierano też związki cywilne („w ratuszu”) i to nie tylko w przypadku osób rozwiedzionych czy braku dokumentów. Jedna z emigrantek, wdowa, przyznała w pamiętniku, że ślub z kuzynem wzięła: „... na korcie ... bo wszyscy ... mówili, że jak się krewni żenią, ksiądz żąda 100 dolarów, a my ich nie mieli"48. Dla wielu pochodzących ze wsi emigrantów nowością musiała być natomiast dostępność cywilnych rozwodów. Brakuje analiz tej sfery, ale materiały zgromadzone przez W.I. Thomasa i F. Znanieckiego potwierdzają, że w rodzinach polskich imigrantów zdarzały się zarówno rozwody i separacje jak i opuszczenia rodziny (najczęściej przez męża, ale czasami przez żonę) ${ }^{49}$. Wśród specyficznych przyczyn trudności rodzinnych i rozpadu małżeństw na emigracji W.I. Thomas i F. Znaniecki wymieniają osłabienie kontroli społecznej, niedostosowanie przywożonych ze Starego Kraju wzorców do warunków amerykańskich oraz zmianę charakteru i znaczenia pracy wykonywanej przez kobiety w domu. Te z nich, które zajmowały się wyłącznie troską o własną rodzinę (gotowaniem, sprzątaniem, naprawą ubrań), nie miały własnych dochodów, które w rodzinnej wsi czerpały z hodowli inwentarza i uprawy ogrodu. W Ameryce mogły jedynie oszczędnie wydawać pieniądze zarobione przez mężów ${ }^{50}$. Sytuacja ta była powodem frustracji i zniechęcenia, a dla wielu kobiet prawdopodobnie także pozaekonomicznym bodźcem do przyjmowania do domu bortników (sublokatorów). Badania dowodzą, że w grupie polskiej system ten był rozpowszechniony bardziej niż wśród innych społeczności o podobnym, emigranckim rodowodzie.

Początek aktywności polskich kobiet w USA wiąże się z parafiami i tworzonymi przy nich kółkami różańcowymi oraz towarzystwami o charakterze religijnym, w których prowadzono również działania samopomocowe. Znaczącą rolę odgrywały też żeńskie zgromadzenia zakonne (zwłaszcza felicjanki, siostry szkolne i franciszkanki) przyjmujące córki emigrantów już od końca lat 60. XIX w. ${ }^{51}$. Wstąpienie do klasztoru podnosiło prestiż rodziny przyszłej zakonnicy, a dla niej samej oznaczało awans społeczny i stwarzało możliwości kształcenia. Siostry pracujące w parafiach, sierocińcach, domach opieki, a przede wszystkim w przykościelnych szkołach, były zależne od lokalnych duchownych i hierarchii kościelnej, otrzymywały niższe wynagrodzenie

48 Pamiętnik nr 18, w: Pamiętniki emigrantów. Stany Zjednoczone..., s. 431.

49 W.I. Thomas, F. Znaniecki (1976), Chłop polski w Europie i Ameryce, t. 5: Organizacja i dezorganizacja w Ameryce, Warszawa: Ludowa Spółdzielnia Wydawnicza, s. 147.

50 Tamże, s. 136-137.

51 W 1902 r. w diecezji Milwaukee powstało nawet polskie zgromadzenie józefitek. Zob. D. Praszałowicz (1999), Stosunki polsko-niemieckie na obczyźnie. Polscy i niemieccy imigranci w Milwaukee, 


\section{SM̂PP}

niż pracownicy świeccy, ale cieszyły się szacunkiem w społeczności polonijnej i miały zapewnione bezpieczeństwo socjalne, co dla wielu z nich było znaczące ${ }^{52}$.

Kobieca organizacja polonijna o charakterze świeckim, ale deklarująca przywiązanie do wiary katolickiej, powstała w USA dopiero w 1898 r. Po kilku nieudanych próbach, grupa aktywistek pochodzących z zaboru pruskiego i - co ważne - wywodzących się z klasy średniej - powołała Związek Polek w Ameryce. Przyciągnął on głównie członkinie ze środowisk robotniczych i stworzył im możliwość ubezpieczenia, do którego nie miały dostępu w innych, kierowanych przez mężczyzn, organizacjach polonijnych. Związek stał się platformą współpracy kobiet o różnym statusie społecznym. Przynależność do tej organizacji wymagała opłacenia składek, a więc członkostwo było uwarunkowane posiadaniem własnego dochodu. Związek Polek opowiadał się za emancypacją kobiet i ich pełnym dostępem do szkół. Wspierał też polonijną oświatę i zachowanie polskiej kultury oraz prowadził akcje pomocy dla Polaków w Kraju. Szybko rozbudował swe struktury lokalne w różnych rejonach USA: w 1906 r. miał ponad 4 tys. członkiń, a 10 lat później ponad 20 tys. Od 1910 r. wydawała też własny periodyk "Głos Polek"53. Aktywność Związku Polek przyczyniła się do powstania nowych towarzystw kobiecych ${ }^{54}$, ale też zmieniła nastawienie do kobiet w innych polonijnych organizacjach. Polki uzyskały w nich nie tylko możliwość ubezpieczenia, ale były dopuszczane do różnych stanowisk. Wszystko to wpłynęło na złagodzenie radykalizmu Związku Polek i zmianę jego programu w kierunku, który Adam Walaszek określa „patriotycznym feminizmem” ${ }^{55}$. Ożywienie społeczności polonijnej związane z I wojną światową, a po niej ograniczenie imigracji z Polski oraz procesy asymilacyjne $w$ grupie polskiej, przynosiły kolejne przekształcenia w Związku Polek i jego ewolucję w kierunku organizacji łączącej działalność ubezpieczeniową, kulturalną i charytatywną. Związek Polek zgromadził znaczny kapitał i do dziś jest jedną z najbardziej wpływowych polonijnych organizacji w USA.

Aktywność polskich emigrantek w kanadyjskich miastach rozpoczęła się później niż w USA, ale częściowo powielała wzory z sąsiedniego kraju. Większość polskich emigrantek trafiała do miast już po jakichś doświadczeniach na preriach. Stosunkowo rzadko podejmowały pracę $w$ rozwijających się dopiero zakładach przemysłowych.

52 M. Borys (2018), Działalność żeńskich zgromadzeń zakonnych wśród Polonii chicagowskiej (1874-1899), "Studia Migracyjne - Przegląd Polonijny”, nr 1, s. 219-239; D. Praszałowicz (2009) Rola żeńskich zakonów religijnych w życiu skupisk polonijnych w Stanach Zjednoczonych, w: Polska - dwa światy. Kraj i Polonia. Materiaty z Międzynarodowej Konferencji Naukowej 'Polacy w Ameryce Północnej - 400 lecie', J.W. Wysocki, W. Gliński (red.), Warszaw: Wydawnictwo UKSW, s. 207-219.

${ }^{53}$ Walaszek, A. (1996), The Polish Women's Alliance in America: Between Feminism and Patriotism Immigrants and Their Children in the USA, 1898-1930, w: Ethnic Fraternalism in Immigrant Countries, M. Klemenčić (red.), Maribor: University of Maribor, s. 197-212.

${ }^{54}$ Np. w roku 1912 w Cleveland utworzono Stowarzyszenie Polek w Stanach Zjednoczonych, które od roku 1923 wydawało własne pismo pt. „Jedność Polek” https://chroniclingamerica.loc.gov/lccn/ sn83035481/1923-07-19/ed-1/seq-1/ [dostęp: 12.06.2019].

55 Walaszek, A. (1996), s. 204-208. 
Te z kobiet, które nie były obciążone rodziną, zarabiały szyjąc lub sprzątając. Podobne zajęcia podejmowały żony emigrantów i wdowy po nich. Niektóre przyjmowały sublokatorów, głównie w zimie, kiedy do miast ściągali robotnicy sezonowi. Przynosiło to zwykle jedynie okresowe dochody. Poza domem emigrantki rozpoczynały działalność od religijnych i samopomocowych towarzystw przy polskich parafiach powstających w miastach. Włączały się też w pracę tworzonych tam szkółek i teatrzyków amatorskich. W 1915 r. w Winnipeg odnotowano nawet istnienie polskiego Ladis' Club promującego abstynencję ${ }^{56}$ i prawdopodobnie związanego z którymś z Kościołów. W dużych miastach, ale też w osiedlach, do których nie docierali katoliccy duchowni, zakładano polskie towarzystwa o charakterze lewicowym, a wśród ich członków i sympatyków znaleźć można także kobiety. Z materiałów zamieszczonych w jubileuszowej księdze Związku Polaków w Kanadzie wynika, że na początku XX w. w Toronto powstało polskie Towarzystwo Pań, gdyż - podobnie jak w USA - samopomocowe organizacje ubezpieczeniowe działające $w$ tym mieście nie przewidywały członkostwa kobiet. Połączyły się one jednak w pierwszej połowie lat 20. XX w. w Związek Polaków w Kanadzie, który zaakceptował prawo kobiet do ubezpieczenia. Panie rozwiązały wówczas swoją organizację, ale od połowy lat 30. XX w. przy kolejnych Grupach Związku powstawały Koła Polek, posiadające pewną autonomię. Model ten stopniowo rozszerzył się na inne Grupy ZPwK57 i został przyjęty również w innych kanadyjskich towarzystwach polonijnych. Pierwsza samodzielna organizacja (Federacja Kobiet Polskich) skupiająca polskie emigrantki i Kanadyjki polskiego pochodzenia, została powołana dopiero w 1957 r.

Specyficznym fragmentem dziejów polskich emigrantek, powiązanym z miastami i od niedawna przyciągającym uwagę historyków, jest handel żywym towarem. Międzynarodowe mafie wysyłały młode dziewczyny z ziem polskich do domów publicznych głównie w Ameryce Południowej, ale też w Rosji, Rumunii, Grecji czy Turcji. Najbardziej znana jest historia Warszawskiego Towarzystwa Wzajemnej Pomocy i Prawidłowego Grzebania „Varsovia”. Szacuje się, że sprowadziło ono około tysiąca kobiet - Żydówek, ale również Polek - do Argentyny. Skala procederu sprawiła, że w tym kraju termin „la polaca” oznaczał prostytutkę. Argentyńska policja, przy współpracy z władzami polskimi, częściowo rozbiła „Varsovię” dopiero pod koniec lat 20. XX w. ${ }^{58}$

${ }^{56}$ H. Radecki (1979), Ethnic Organizational Dynamics. The Polish Group in Canada, Waterloo, Ont.: Wilfrid Laurier University Press, s. 51.

57 T. Szramek (2008), Wczoraj i dziś Związku Polaków w Kanadzie [księga pamiątkowa], Toronto, s. $40-41$.

58 Zob. Drogi hańby. Piśmiennictwo polskie o handlu „żywym towarem” (2013), R. Antonów (red.), Wrocław: Wydział Prawa, Administracji i Ekonomii Uniwersytetu Wrocławskiego. Zbeletryzowaną wersję tej historii przedstawia książka I. Vincent (2006), Ciała i dusze, Wrocław: Wydawnictwo Dolnośląskie. 


\section{SMAPP}

\section{Uciekinierki i aktywistki z okresu I wojny światowej}

Odmienne problemy w odniesieniu do migracji kobiet, przyniosła I wojna. Zdolni do noszenia broni mężczyźni trafiali do walczących ze sobą armii. Wojenne doświadczenia kobiet na ziemiach polskich, niezależnie od regionu zamieszkania i pozycji społecznej, to ucieczki, tułactwo, trudne powroty. Postacie kobiet dominują na nielicznych zachowanych zdjęciach taborów bieżeńców i obozów dla uchodźców wojennych. Wycinki tej tematyki i przekazywana przez kilka pokoleń pamięć o doświadczeniach ludności cywilnej z okresu I wojny światowej, powoli przyciągają zainteresowanie historyków ${ }^{59}$, choć wiele zagadnień czeka jeszcze na opracowanie.

$\mathrm{Na}$ odnotowanie zasługuje natomiast zaangażowanie Polek i Amerykanek polskiego pochodzenia na rzecz sprawy polskiej w czasie I wojny światowej. Związek Polek w Ameryce wspierał rekrutację ochotników do tworzonej we Francji polskiej Armii Błękitnej, których szkolono w Kanadzie. Aktywistki robiły dla nich ciepłe swetry, szaliki i skarpetki oraz haftowały sztandary. Sokolice - dziewczęta i młode kobiety należące do towarzystwa gimnastycznego Związek Sokołów Polskich w Ameryce - odbywały kursy sanitarne i praktyki szpitalne przygotowujące do służby medycznej na froncie ${ }^{60}$. W lutym 1918 r. z inicjatywy Heleny Paderewskiej i przy wsparciu większości polonijnych organizacji kobiecych, powstał w USA Polski Biały Krzyż skupiający głównie kobiety. Organizował on pomoc dla polskich żołnierzy i inwalidów oraz ich rodzin. Prowadził też zbiórki oraz wysyłał na front ciepłą bieliznę, papierosy, leki, materiały opatrunkowe, książki, prasę i gry towarzyskie. Wyszkolono i wysłano do Francji 42 sanitariuszki. Po zakończeniu wojny działaczki Polskiego Białego Krzyża włączyły się $w$ akcję organizowania powrotu amerykańskich weteranów Błękitnej Armii do USA ${ }^{61}$. W 1925 r. wraz z innymi polonijnymi aktywistkami, stworzyły natomiast Korpus Pomocniczy Pań przy Stowarzyszeniu Weteranów Armii Polskiej. W sytuacjach oficjalnych "korpusianki" występowały w charakterystycznych niebieskich pelerynkach. Była to rozbudowana i dobrze zorganizowana struktura kobieca prowadząca na terenie USA i Kanady zbiórki i różnego rodzaju akcje charytatywne na rzecz polskich weteranów. Na co dzień członkinie Korpusu poszukiwały pracy dla bezrobotnych byłych polskich żołnierzy, potrzebującym dostarczały żywność i leki, opiekowały się chorymi, prowadziły kilka schronisk i przytułków dla inwalidów oraz otaczały opieką groby zmarłych ${ }^{62}$. Jako „korpusianki" działały żony i rodziny weteranów, ale też inne

${ }^{59}$ A. Prymaka-Oniszek (2016), Bieżeństwo, "Karta” nr 86, s. 8-23; U. Oettingen (2010), Migracje ziemianek w latach I wojny światowej - uwarunkowania i wpływ na styl życia, w: Kobiety i procesy..., s. 127-149; K. Sierakowska, Kobiety - uchodźcy z ziem polskich w czasie I wojny światowej - kilka refleksji, w: Kobiety i procesy..., s. 151-159.

${ }^{60}$ A. Maksymowicz (2015), s. 35.

61 Tamże, s. 69-74 i 96-114.

62 Organizacja ta działa do dziś; w szczytowym okresie swego rozwoju miała ponad 100 placówek i ponad 4,5 tysiąca członkiń w USA i Kanadzie. Tamże, s. 155-157, 177. 
kobiety, traktujące swe zaangażowanie jako pracę społeczną czy pożyteczną formę spędzania wolnego czasu. Warto zwrócić uwagę, że aktywność ta była połączeniem wywodzącej się z polskiej tradycji roli kobiety - opiekunki z amerykańskimi metodami pomocy weteranom organizowanej przez państwo.

\section{Emigrantki w okresie międzywojennym}

Powstanie niepodległej Rzeczpospolitej, w której zagwarantowano równe prawa kobietom, nie zahamowało emigracji. Wbrew wielu nadziejom kontynuowane były zarówno wyjazdy sezonowe jak i osadnicze i we wszystkich uczestniczyły kobiety. Wprowadzenie w USA ograniczeń kwotowych sprawiło, że po 1922 r. z Polski wyjeżdżali tam głównie niepracujący członkowie rodzin ${ }^{63}$. Otwarły się natomiast nowe, głównie europejskie, kierunki migracji. Badacze szacują, że w latach 1918-1938 Polskę opuściło ponad 2,2 miliona osób, z czego ponad 60\% trafiło do krajów europejskich ${ }^{64}$. Wielkość i skład tych ruchów kształtowała jednak aktualna koniunktura gospodarcza oraz polityka państw przyjmujących. W kilku z nich (we Francji, w Danii, na Litwie, na Łotwie i w omawianej wcześniej Kandzie) pojawiło się zapotrzebowanie na pracę kobiet; najczęściej w rolnictwie lub w charakterze służby domowej. Statystyki zawierające dane na temat struktury demograficznej emigracji z Polski sporządzano jednak dopiero od 1927 r. Bilans dla lat 1927-1938 wskazuje na niewielką przewagę kobiet wśród wyjeżdżających (różnica 41 tysięcy, co stanowił 3\% całego ruchu - zob. Tabele nr 1 i 2).

W zestawieniach obejmujących wyłącznie emigrację europejską przewaga ta jest jednak wyraźniejsza65. W czasie koniunktury gospodarczej lat 20. XX w., przy znacznym nasileniu emigracji, większość wyjeżdżających stanowili mężczyźni, choć udział kobiet w całym ruchu stopniowo wzrastał. Zdecydowanie dominowały one natomiast wśród osób wyjeżdzających z Polski w kryzysowych latach 30. XX w. Emigrantki czynne zawodowo uważane były wówczas za tańszą siłę roboczą i miały relatywnie większe możliwości znalezienia pracy. W tym samym czasie kobiety zawodowo bierne mogły też, łatwiej niż mężczyźni, ominąć ograniczenia imigracyjne i dołączyć do rodziny przebywającej za granicą ${ }^{66}$. Wzrost udziału kobiet wśród emigrantów z II Rzeczpospolitej, fakt że pewien ich odsetek uczęszczał do polskich szkół, że legitymowały się one polskimi paszportami oraz to, że tak w czasie podróży, jak

63 Tamże, s. 91.

64 E. Kołodziej (1982), Wychodźstwo zarobkowe z Polski Studia nad polityką emigracyjną /I Rzeczpospolitej, Warszawa: Krajowa Agencja Wydawnicza, s. 253.

65 Waha się ona w zależności od roku między 46,3\% a 41,4\%, choć w przypadku aż 12\% emigrujących brakuje informacji na temat płci. Zob. Kołodziej (1982), s. 153.

66 Ciekawe, że przewaga kobiet wśród emigrantów z latach kryzysu, widoczna jest nawet w zestawieniach osób wyjeżdżających z Polski do Palestyny, mimo że ruch ten miał wyłącznie charakter osadniczy. 
Tabela nr 1

Udział kobiet w emigracji z II Rzeczpospolitej w latach 1927-1938

\begin{tabular}{|l|c|c|c|}
\hline Rok & $\begin{array}{c}\text { Emigranci ogółem } \\
\text { (w tys.) }\end{array}$ & $\begin{array}{c}\text { Kobiety } \\
\text { (w tys.) }\end{array}$ & \% Kobiet \\
\hline 1927 & 147,5 & 72,0 & 48,8 \\
\hline 1928 & 186,5 & 88,0 & 47,2 \\
\hline 1929 & 243,5 & 114,0 & 46,8 \\
\hline 1930 & 218,0 & 103,0 & 47,1 \\
\hline 1931 & 76,0 & 53,0 & 69,7 \\
\hline 1932 & 21,5 & 14,5 & 67,4 \\
\hline 1933 & 35,5 & 23,5 & 66,2 \\
\hline 1934 & 42,5 & 27,0 & 63,5 \\
\hline 1935 & 54,0 & 34,0 & 63,0 \\
\hline 1936 & 55,5 & 33,0 & 60,0 \\
\hline 1937 & 102,5 & 52,3 & 51,2 \\
\hline 1938 & 129,0 & 67,0 & 51,9 \\
\hline $1927-1938$ & 1312,0 & 691,5 & 52,7 \\
\hline
\end{tabular}

Źródło: H. Janowska (1984), Emigracja z Polski w latach 1927-1939, w: Emigracja z ziem polskich w czasach nowożytnych i najnowszych (XVIII-XX w.), A. Pilch (red.), Warszawa: PWN, s. 435.

Tabela $\mathrm{nr} 2$

Udział kobiet w głównych kierunkach emigracji z II Rzeczpospolitej w latach 1927-1938

\begin{tabular}{|l|c|c|c|c|c|c|}
\hline \multicolumn{1}{|c|}{ Kraj } & $\begin{array}{c}\text { Emigranci } \\
\text { ogółem } \\
\text { (w tys.) }\end{array}$ & $\begin{array}{c}\text { Kobiety } \\
\text { (w tys.) }\end{array}$ & $\begin{array}{c}\text { \% } \\
\text { Kobiet }\end{array}$ & $\begin{array}{c}\text { Emigranci } \\
\text { ogółem } \\
\text { (w tys.) }\end{array}$ & $\begin{array}{c}\text { Kobiety } \\
\text { (w tys.) }\end{array}$ & $\begin{array}{c}\% \\
\text { Kobiet }\end{array}$ \\
\hline Francja & 216,3 & 66,6 & 31 & 119,4 & 64,0 & 54 \\
\hline Belgia & 12,3 & 4,1 & 31 & 12,2 & 6,2 & 51 \\
\hline Kanada & 87,6 & 32,4 & 36 & 12,3 & 7,3 & 59 \\
\hline Argentyna & 77,1 & 16,6 & 21,5 & 33,8 & 18,7 & 55 \\
\hline USA & 31,4 & 18,9 & 55 & 12,4 & 7,1 & 57 \\
\hline Brazylia & 19,9 & 7,5 & 37 & 12,2 & 4,7 & 38 \\
\hline Palestyna & 5,5 & 2,9 & 53 & 62,8 & 34,2 & 54 \\
\hline
\end{tabular}

Źródło: H. Janowska (1984), Emigracja z Polski w latach 1927-1939, w: Emigracja z ziem polskich w czasach nowożytnych i najnowszych (XVIII-XX w.), A. Pilch (red.), Warszawa: PWN, s. 436-437. 
i pobytu za granicą zostały - choć często jedynie teoretycznie - objęte opieką władz polskich, tworzy zestaw elementów odróżniających falę emigracji międzywojennej od fal wcześniejszych.

Krajem, który w latach 20 i 30. XX w. przyciągnął znaczną ilość polskich migrantów, głównie sezonowych, były Niemcy. Szacunki określają wielkość tego ruchu nawet na 50 tys. rocznie.

W związku z napięciami w stosunkach polsko-niemieckich i brakiem regulacji prawnych była to jednak aż do 1926r. emigracja nielegalna. Wyjazdy do pracy w Niemczech zostały dodatkowo zawieszone w latach 1930-37 w związku z kryzysem ekonomicznym. Nie stanowiło to jednak bariery dla emigracji nielegalnej i wiadomo, że uczestniczyły w niej również kobiety. Charakter przeważającej części wymienionego wyżej ruchu uniemożliwia jednak jego badanie.

\section{Polki we Francji}

Bariery w emigracji do Niemiec i USA sprawiły, że nowym kierunkiem wyjazdów zarobkowych z Polski stała się po I wojnie światowej Francja. Już w 1919 r. władze Rzeczpospolitej zawarły z tym krajem konwencję emigracyjną. Zezwalała ona misjom francuskim na rekrutację i selekcję w Polsce górników, robotników przemysłowych oraz pracowników rolnych, także kobiet. Te ostanie kierowano zarówno do pracy w przemyśle jak i w rolnictwie. Zatrudniano je również w charakterze służby domowej. Kobiety wyjeżdżały więc do Francji albo z rodzinami, albo dołączały do mężów czy krewnych, albo emigrowały samodzielnie. Czasem to one sprowadzały członków rodziny. Podstawowym motywem większości tych wyjazdów była poprawa sytuacji materialnej. W prasie emigracyjnej zarejestrowano jednak opinie dziewcząt deklarujących, że marzą o wyjeździe do Paryża, używaniu życia i ładnych strojach, a kontrakty pracy na roli wyobrażają sobie jedynie jako pomost do realizacji tych marzeń ${ }^{67}$. Polsko-francuska konwencja emigracyjna zobowiązywała francuskich pracodawców oraz władze Francji do traktowania polskich pracowników na równi z własnymi obywatelami. Zakładała też objęcie imigrantów ubezpieczeniami i opieką społeczną (w tym systemem zasiłków chorobowych oraz macierzyńskich). W praktyce jednak Francuzi nie zawsze realizowali warunki umowy, a polscy robotnicy i robotnice otrzymywali na ogół jedynie okresowe kontrakty pracy i wynagrodzenie niższe niż Francuzi. Napływ imigrantów był też uzależniony od koniunktury gospodarczej. W stosunku do bezrobotnych stosowano ekspulsję ${ }^{68}$. Z danych statystycznych wynika, że w okresie międzywojennym z Polski do Francji wyjechało około 600 tys. osób i około 100 tys.

67 J. Dufrant, Migracje Polek do Francji w okresie międzywojennym, w: Kobiety i procesy..., s. 164.

${ }^{68}$ H. Janowska (1964), Polska emigracja zarobkowa we Francji 1919-1939, Warszawa: Książka i Wie- 
Polaków z Zagłębia Ruhry. Liczba kobiet w obu tych grupach szacowana jest pomiędzy 167 a 180 tys. ${ }^{69}$.

Poza statystykami niewiele jest źródeł ilustrujących losy polskich emigrantek we Francji. Wśród 49 nadesłanych i 35 opublikowanych w 1939 r. pamiętników są jedynie trzy wspomnienia napisane przez kobiety. Być może wiązało się to z brakiem zainteresowania potencjalnych autorek lub z ich problemami z pisaniem (wiadomo, że wyjeżdżały również analfabetki). Podobnie jak we wszystkich przywoływanych wcześniej przypadkach, w pamiętnikach mężczyzn informacje o kobietach występują stosunkowo rzadko, ale kilka z nich jest ciekawych. W opisach podróży do Francji zarejestrowane zostały generalnie trudy oraz przykre doświadczenia. Odnosiło się to zwłaszcza do kobiet wyjeżdzających z dziećmi. Emigrantka, żona górnika, wspominała o swoich obawach przed wyjazdem, opisała uciążliwe formalności, krępujące badania lekarskie, noclegi we wspólnych salach i na piętrowych łóżkach, zatłoczone perony, a także kompletnie nieprzystosowane wagony. Kobietę przerażał tłum, pośpiech i niewygody ${ }^{70}$.

Fala emigrantów docierająca z II Rzeczpospolitej do Francji nie była jednolita i różnie toczyły się w jej ramach losy kobiet. Część przybywających wywodziła się ze środowisk górniczych i robotniczych. Emigrantki należące do tej grupy przyjeżdżały z rodzinami lub do rodzin i osiedlały się w ośrodkach przemysłowych, głównie w północnej Francji oraz w rejonie podparyskim. Do tych samych ośrodków kierowały się także rodziny polskich górników z Westfalii. Również tam docierali mieszkańcy polskich wsi poszukujący pracy w przemyśle. Do niektórych z nich, zwykle po kilku latach, dołączały rodziny. Większość wymienionych wyżej przybyszy tworzyła polskie skupiska w osadach robotniczych i miasteczkach przykopalnianych. Dzierżawili tam, a po pewnym czasie kupowali, domy lub kilkupokojowe mieszkania, które po zagospodarowaniu były przedmiotem dumy i dowodem awansu ekonomicznego. Rodziny górników, hutników oraz innych pracowników przemysłu ciężkiego, zwłaszcza te, w których zarabiały też dorastające dzieci, cieszyły się generalnie względnym dobrobytem. Żony pracowników tej kategorii zazwyczaj zajmowały się domem i dziećmi (zwykle liczną gromadką), a często także przydomowym ogrodem, gdzie poza uprawą warzyw, często hodowały drób, króliki, a nawet prosięta. W przyzakładowych osiedlach Polki wytwarzały sieci społeczne, w których wymieniały informacje i wzajemnie się wspierały.

${ }^{69}$ Szacunki dla lat 1919-1925 podają, że wyjechało około 60 tys. kobiet. Dane statystyczne dla lat 1927-1930 mówią o 66,6 tys. (31\% ogółu emigrujących z Polski do Francji), a dla lat 1931-1938 prawie o 64 tys. (54\% ogółu). Zob. W. Śladkowski (2002), Polska diaspora we Francji 1871-1999, w: Polska diaspora, s. 181-183; J. Dufrat (2010), Migracje Polek do Francji w okresie międzywojennym, w: Kobiety a procesy..., s. 163. Francuski spis powszechny, który obejmował również urodzone we Francji dzieci imigrantów, odnotował w roku 1936 ponad 422 tys. obywateli polskich, w tym 191,6 tys. kobiet A. Nowakowska-Wierzchoś (2009), Życie codzienne polskich emigrantek w okupowanej Francji 1940-1944 (cz.1) https:// histmag.org/Zycie-codzienne-polskich-emigrantek-w-okupowanej-Francji-1940-1944-cz.-1-3581/1/1 [data dostępu: 28.02.2019].

70 Pamiętnik nr3, w: Pamiętniki emigrantów. Francja, s. 39-40. [zachowano pisownię oryginału]. 
Łączył je wspólny język i obyczaje, ale też izolacja od francuskich sąsiadek wynikająca z nieznajomości lub słabej znajomości francuskiego oraz lokalnych zwyczajów. Pracę poza domem podejmowały częściej córki górników oraz rodziny słabiej opłacanych polskich robotników. Znajdowały ją głównie w przemyśle lekkim, np. w zakładach włókienniczych i odzieżowych czy hutach szkła. Niektóre Polki zatrudniano jednak nawet w kopalniach, np. przy segregowaniu węgla na powierzchni.

Podniesienie poziomu życia i stabilizacja materialna przynosiła emigrantkom z Polski zadowolenie. Nie miały wielkich oczekiwań, ale dostrzegały pozytywy życia we Francji. Potwierdza to opinia jednej z pamiętnikarek: „...nędza jaką przechodziłam w kraju a tu jednak inaczej praca jest i chleba nie brak..."71. Imigrantki podziwiały też, doceniały i wykorzystywały dostępne we Francji zdobycze cywilizacyjne. Jedna z pamiętnikarek napisała: „... domy wszystko piętrowe... aż pięć izbów, dwie u góry, trzy na dole nawet woda w mieszkaniu. Jest nam dobrze". Ta sama autorka w innym miejscu stwierdziła: „...do miasta niedaleko, ale chodzić nie potrzeba bo wszędzie autobusem zajedzie... w wolnych chwilach idziemy do kina aby sobie czas rozerwać i na zabawę też, ale nie często bo to kosztuje a my jesteśmy na obczyźnie"72. Żony polskich górników gospodarowały zwykle bardzo oszczędnie. Same szyły bieliznę i suknie. Czasem źródłem dodatkowych dochodów byli sublokatorzy (nazywani tam „kwaternikami”) oraz stołownicy. Idealny wzorzec „czerstwej rodziny” został przez jednego z imigrantów zilustrowany kilkoma określeniami: dostatek omaszczonego chleba, "codziennie na obiad mięso", buty i stosowne czyste ubranie, brak długów i kłótni w domu, żona szanująca męża, który nie jest ani pijakiem, ani próżniakiem³. Ten sam autor przyznał jednak, że nie wszystkie rodziny funkcjonowały zgodnie z tym wzorem. We wspomnieniach mężczyzn pojawiają się informacje o bardzo wczesnym wydawaniu za mąż córek (nawet piętnastolatek), co, przynajmniej częściowo, wynikało z braku na emigracji kandydatek na żony. Pamiętnikarze wspominają też o innych problemach skupisk polskich: że zdarzali się mężczyźni, którzy mając rodziny w Polsce żyli z „dziewczynami na knebel”, że niewierne żony uciekały ze stołownikami oraz że dzieci z „wolnej miłości” oddawano do - nieznanych w Polsce a rozbudowanych we Francji - świeckich ośrodków opiekuńczych ${ }^{74}$. Wymienione przypadki świadczą o rozluźnieniu obyczajów, ale też kontroli społecznej w skupiskach emigrantów. Brak źródeł nie pozwala na ocenę skali tych zjawisk i na rekonstrukcję losu kobiet porzucanych.

Większość wspomnień dowodzi, że emigracja i nowe warunki zwykle wywoływały pozytywne zmiany w materialnym położeniu kobiet trafiających do osiedli robotniczych. Przeważnie adoptowały się one do otoczenia, wykorzystywały możliwości stwarzane przez pracodawców męża i przystosowywały je do tradycyjnego modelu rodziny przywiezionego z polskiej wsi. Pozycję żon wzmacniała ich zaradność

71 Pamiętnik nr 3, w: Pamiętniki emigrantów. Francja..., s. 42.

72 Tamże, s. 43-6, [zachowano pisownię oryginału].

73 Pamiętnik nr 10, w: Pamiętniki emigrantów. Francja..., s. 166-169.

74 Tamże. 


\section{SM̂PP}

i gospodarność. Każdy poważny problem (wypadek w kopalni, choroba czy nadużywanie przez męża alkoholu) doprowadzały jednak całe rodziny do skrajnej nędzy. Utrata pracy oznaczała często także utratę mieszkania i zagrożenie deportacją. W okresie wielkiego kryzysu wiele polskich rodzin wróciło z Francji do Polski.

Wracało wówczas również wiele Polek, które wyjeżdżały do Francji na kontrakty w gospodarstwach rolnych. Stanowity one w tym kraju około 30\% zawodowo czynnych polskich emigrantek. Sytuacja większości z nich była jednak trudna nie tylko w latach 30. XX w. Nie znające języka, rozproszone po odległych od miast farmach, izolowane, całkowicie zależne od nie zawsze uczciwych pracodawców, były często eksploatowane kilkunastogodzinną, codzienną pracą, wykorzystywane i oszukiwane. Znaczna ich część mieszkała w trudnych warunkach (na strychach, nawet w chlewach). Zdarzało się, że gwałcili je „patroni” lub współpracownicy (także Polacy). Wiele z nich słabo pisała po polsku i nie potrafiła nawet szukać pomocy. Były samotne i bezradne. Te, które decydowały się na powrót, nie posiadając środków na opłacenie podróży były narażone na aresztowanie za włóczęgostwo lub wpadnięcie w sidła handlarzy żywym towarem ${ }^{75}$. Podobne niebezpieczeństwa groziły tym emigrantkom, które uciekały od pracodawców i poszukiwały jakiejkolwiek pracy. Pod wpływem informacji docierających z Francji władze polskie próbowały ograniczyć rekrutację kobiet - emigrantek, zwłaszcza analfabetek i osób niezamężnych poniżej 30. roku życia. Władze francuskie powołały natomiast sieć inspektorów imigracyjnych ${ }^{76}$. Skutek tych działań był jednak niewielki.

Odrębnym, ciekawym problemem jest zaangażowanie relatywnie dużej części żyjących we Francji polskich emigrantek w działalność społeczną, a także polityczną. Odnosi się to głównie do osób mieszkających w miastach i w ośrodkach przemysłowych, choć niewyłącznie. Polki należały tam zarówno do bractw różańcowych, towarzystw katolickich, chórów, zespołów tanecznych i do organizacji oświatowych, jak i do kół wspierających polonijne gazety ${ }^{77}$ oraz do lewicowego Towarzystwa Uniwersytetów

75 Dufrat J. (2010), Migracje Polek do Francji w okresie międzywojennym, w: Kobiety i procesy migracji..., s. 178.

76 Jedną z takich inspektorek została Julie Duval. Zachowana jej korespondencja z polskimi emigrantkami została we Francji opublikowana w zbiorze pt. Polonais aux champ. Lettres de femmes immigrées dan les campagnes françaises (1930-1935), (2015), S. Aprile, M. Laurent, J. Ponty, (red.). Paris: Numilog 2015. Sama J. Duval (Julia Michalina Krystyna z domu Lachowicz) jest też ciekawym przykładem emigrantki. Urodziła się i wychowała we Lwowie, wyszła za mąż za lektora języka francuskiego pracującego na Politechnice Lwowskiej; w czasie I wojny wyjechała z synem do Francji, a następnie do Maroka. W 1928 r., prawdopodobnie po rozwodzie, wróciła do Francji. Zob.: M. Laurent, Une intelectuelle en action, w: Polonais aux champ..., s. 235-257).

77 Na uwagę zasługuje "Ognisko" pismo wydawane od lutego 1922 r. w Paryżu, którego założycielką i wydawcą była Maria Szeliga (pseudonim Marii Loevy-Czarnowskiej aktywnej działaczki społecznej z końca XIX w.); po jej śmierci pismem kierowała Ewa Mickun, adwokatka specjalizująca się w sprawach emigracyjnych. Gazeta miała kilka tysięcy nakładu i sympatyzowała z przeciwnikami Sanacji. Poczytnym, lewicowym „Robotnikiem Polskim” w latach 1937-1938 kierowała Estera Golde-Stróżewska. Zob. A. Paczkowski (1969), Prasa polska we Francji (1918-1940), "Roczniki Historii Czasopiśmiennictwa Polskiego”, nr 4, s. 521-536. 
Robotniczych, Polskich Grup Czerwonej Pomocy, a także do polskiej sekcji francuskich związków zawodowych. Udokumentowana, znacząca aktywność Polek we francuskim ruchu oporu w czasie II wojny światowej ${ }^{78}$ bazowała na wcześniejszej współpracy części polskich środowisk emigracyjnych (w tym kobiet) z działaczami francuskimi. Jest to jednak sfera wymagająca nowej interpretacji, zarówno źródeł, jak i istniejącej literatury.

\section{Podsumowanie}

Pobieżny przegląd najważniejszych polskich strumieni migracyjnych przed II wojną światową ukazuje, że stopniowo wzrastał w nich udział kobiet. Wachlarz ich losów i doświadczeń w wielu aspektach różnił się od tych, które były udziałem mężczyzn, tak uchodźców jak i emigrantów. W niektórych przypadkach wynikało to z okoliczności podróży, zwłaszcza gdy kobiety z dziećmi dołączały do mężów lub członków rodziny, albo podróżowały samotnie do nieznanych sobie krajów. Większość różnic była jednak związana z odmienną pozycją kobiet. Przenoszenie z ziem polskich tradycyjnych ról i obowiązków wymagających od kobiet dbania o ognisko domowe i zachowanie zwyczajów udawało się, zwykle przy ogromnym wysiłku, jedynie (i nie zawsze) w przypadkach emigracji politycznej oraz wyjazdów całych rodzin i osiedlaniu się ich na roli, z dala od ośrodków miejskich. Taka prosta rekonstrukcja nie była generalnie możliwa w odniesieniu do Polek emigrantek, które z rodziną, lub samodzielnie, trafiały do miast czy ośrodków przemysłowych. Zmiany ich ról i aktywizacja pewnej ich części (także drugiego pokolenia) zależały od wielu czynników, głównie od kraju i miejsca osiedlenia, okresu emigracji, statusu społecznego i poziomu edukacji. W niektórych sytuacjach zmiana pozycji kobiet następowała szybko i radykalnie, w innych była powolnym procesem adaptacji, łączeniem tradycyjnie polskich wzorców z nowymi elementami czerpanymi zarówno z doświadczeń życia w diasporze jak i z realiów kraju osiedlenia. Realia te także ulegały modyfikacjom. Losy i pozycja emigrantek podlegała więc swoistym meandrom, zależnym również od polityki państwa, do którego trafiały jak i od nastawienia i stopnia oraz charakteru kontaktów emigrantek z lokalną społecznością. Przełamywanie barier i przyjmowanie nowych wzorców, a w konsekwencji poprawa pozycji polskich imigrantek, następowały szybciej tam, gdzie okazywano im zainteresowanie i wspierano ich wysiłki. Pokazują to zarówno przykłady aktywności społeczników w Danii jak i struktur lewicowych we Francji. Nie ma niestety prac analizujących stosunek do imigrantek w programach oraz działaniach organizacji i ruchów emancypacyjnych oraz feministycznych w krajach osiedlania Polek i to zagadnienie jest propozycją dla przyszłych badaczy.

78 K. Kozłowska (1974), Polki w Résistane. Z walk lewicowego ruchu oporu we Francji, Warszawa MON 


\section{SM̂PP}

Zmiany pozycji kobiet w obrębie skupisk polskiej diaspory w USA przynosiła, a właściwie wymuszała, ponadlokalna współpraca kobiet i determinacja grona działaczek. Wzory te interesowały i - jak pokazuje przykład kanadyjski - oddziaływały na inne skupiska polskiej diaspory. Warto prześledzić ich wpływ na polską diasporę w innych krajach. Konieczne jest dalsze prowadzenie szczegółowych badań nad różnymi wycinkami i aspektami procesów migracyjnych Polek oraz różnymi formami ich aktywności w krajach osiedlenia. Wartościowe są też wszelkie badania porównawcze. Odnosi się to przede wszystkim do porównywania roli kobiet w różnych strumieniach migracyjnych oraz w różnych krajach osiedlenia. Ukazuje to analogie przekraczające granice geograficzne i czasowe (np. sprowadzanie kandydatek na żony czy praca towarzystw przyparafialnych). Ciekawe rezultaty mogą przynieść także badania porównawcze doświadczeń i wzajemnych relacji Polek z emigrantkami z innych krajów, które osiedlały się w tym samym miejscu. Najważniejszymi postulatami pozostaje jednak zwracanie uwagi na specyfikę doświadczeń emigrantek i ich aktywności w diasporze oraz poszukiwanie źródeł historycznych obrazujących te zjawiska i procesy. Niezwykle pomocne dla tej tematyki, choć niełatwe do przeprowadzenia, mogą być kwerendy w polskojęzycznej prasie wydawanej na emigracji. Dalekosiężnym postulatem jest tworzenie prac przeglądowych i budowa syntezy ukazującej pełny, wielowymiarowy obraz, zarówno dziejów migracji polskich kobiet jak i ich roli w społecznościach tworzonych poza Polską. Będzie

to dopełnieniem nie tylko historii polskiej emigracji i polskiej diaspory, ale przyczyni się również do lepszego poznania i zrozumienia wielu aspektów dziejów Polski.

\section{Bibliografia}

Baranowski B., Baranowski K. (1985), Polaków kaukaskie drogi, Łódź: KAW.

Banaszkiewicz M. (2017), Antropolog wobec odmienności kulturowej i przyrodniczej. Refleksje Marii Czaplickiej z ekspedycji na Syberię, „Studia Etnologiczne i Antropologiczne”, nr 17.

Blank J.C. (2016), Creating Kashubia. History, Memory, and Identity in Canada's First Polish Community, Montreal: McGill University.

Bobrowska E. (2012), Emancypantki? Artystki polskie w Paryżu na przełomie XIX i XX w. "Archiwum Emigracji. Studia - Szkice - Dokumenty", nr 1-2, s. 11-27.

Borys M. (2018), Działalność żeńskich zgromadzeń zakonnych wśród Polonii chicagowskiej (18741899), "Studia Migracyjne - Przegląd Polonijny”, nr 1, s. 219-239.

Brożek A. (1972), Ślązacy w Teksasie, Opole: Instytut Śląski.

Cygan M.E. (1994), Polish Women and Emigrant Husbends, w: Roots of the Transplanted, vol.1: Late 19th Century East Central and Southeastern Europe, D. Hoerder, I. Blank (red.), New York. Drogi hańby. Piśmiennictwo polskie o handlu „żywym towarem” (2013), R. Antonów (red.), Wrocław: Wydział Prawa, Administracji i Ekonomii Uniwersytetu Wrocławskiego.

Duda-Dziewierz K. (1938), Wieś małopolska a emigracja amerykańska. Studium wsi Babica powiatu rzeszowskiego, Warszawa-Poznań.

Dufrat J. (2010), Migracje Polek do Francji w okresie międzywojennym, w: Kobiety i procesy migracyjne, A. Chlebowska, K. Sierakowska (red.), Neriton: Warszawa. 
Gmurczyk-Wrońska M. (1996), Polacy we Francji w latach 1871-1914. Spoteczność polska i jej podstawy materialne, Warszawa: Neriton.

Ickiewicz K. (2008), Kaszubi w Kanadzie, Gdańsk: ZG Zrzeszenia Kaszubsko-Pomorskiego.

Janowska H. (1964), Polska emigracja zarobkowa we Francji 1919-1939, Warszawa: Książka i Wiedza.

Jarochowska M.A. (2006), Poza gniazdem. Wizerunek emigrantki polskiej w Kanadzie w XX w., Montreal: Polski Instytut Naukowy w Kanadzie.

Jędrychowska B. (2014), Żony XIX-wiecznych zesłańców jako organizatorki życia rodzinnego na Syberii, „Wychowanie w Rodzinie” t. IX, nr 1, s. 161-173.

Kalembka S. (1971), Wielka Emigracja. Polskie Wychodźstwo Polityczne w latach 1831-1862, Warszawa: Książka i Wiedza.

Knothe M.A. (1997), Recent Arrivals: Polish Immigrant Women's Response to the City, w: Peasant Maids - City Women. From the European Countryside to Urban America, Ch.

Harzig (red.), Ithaca and London: Cornell University Press.

Kobiety i procesy migracyjne (2010), A. Chlebowska, K. Sierakowska (red.), Neriton: Warszawa.

Kolbuszewska J. (2017), Polki na uniwersytetach - trudne początki, "Sesus Historiae”, 2017/1, s. $35-53$.

Kołodziej E. (1982), Wychodźstwo zarobkowe z Polski. Studia nad polityką emigracyjną II Rzeczpospolitej, Warszawa: Krajowa Agencja Wydawnicza.

Konopka J.A. (2010), Polacy na uniwersytecie w Genewie i Polonica biblioteki uniwersyteckiej (lata 1817-1917) http://skryba.inib.uj.edu.pl/goscie/JAK/2010/JAK-2010.pdf.

Kościelecka S. (1983), Dzieje Polonii w Danii w latach 1892-1940, Szczecin: WSP.

Kowalski M.A. (1970), Polacy w Danii, „Etnografia Polska”. T. XIV z.1, s. 57-73.

Kozłowska K. (1974), Polki w Résistane. Z walk lewicowego ruchu oporu we Francji, Warszawa MON. Kozłowski J. (1984), Emigracja u schyłku Rzeczpospolitej szlacheckiej i początki emigracji porozbiorowej, w: Emigracja w czasach nowożytnych i najnowszych, A. Pilch (red.), Warszawa: PWN. Kozłowski J. (1992), Polacy w Niemczech w XIX i XX w., w: Polonia w Europie, B. Szydłowska-Ceglowa (red.), Poznań: Zakład Badań Narodowościowych PAN, s. 223-243.

Kubica-Heller G. (2015), Maria Czaplicka - płeć, szamanizm, rasa: biografia. antropologiczna, Kraków: WUJ.

Later-Chodyłowa E. (1992), Polonia w krajach skandynawskich - Dania w: Polonia w Europie, B. Szydłowska-Ceglowa (red.), Poznań: Zakład Badań Narodowościowych PAN, s. 571-627.

Lenartowicz Ś. (2012), Podróże Zofii Stryjeńskiej i ich paryskie etapy, „Archiwum Emigracji. Studia - Szkice - Dokumenty", nr 1-2, s. 101-115.

Maksymowicz A. (2015), Agnieszka Wisła i działalność Polek w Ameryce na rzecz ochotników i weteranów Błękitnej Armii, Nowy Jork-Opole: Stowarzyszenie Weteranów Armii Polskiej w Ameryce.

Markiewicz A. (2018), Kobiety i rodziny powstańców styczniowych zesłanych w głąb Rosji, Warszawa: Difin.

Marynia Don't Cry: Memoirs of Two Polish-Canadian Families (1995), A. Kojder, B. Głogowska (red.), Toronto: Multiculural History Society of Ontario.

Molenda J. (1997), Miejsce kobiet wśród polskiego wychodźstwa w reńsko-westfalskim okręgu przemysłowym na początku XX w., „Przegląd Historyczny” nr 1/1997, s. 117-134.

Morawska E. (1985), For Bread with Batter: The Life-Worlds of East Central Europeans in Johnstown, Pennsylvania 1890-1940, New York: Cambridge University Press. 


\section{SM̂PP}

Nowakowska-Wierzchoś A. (2009), Życie codzienne polskich emigrantek w okupowanej Francji 1940-1944 (cz.1) https://histmag.org/Zycie-codzienne-polskich-emigrantek-w-okupowanejFrancji-1940-1944-cz.-1-3581/1/1.

Paczkowski A. (1969), Prasa polska we Francji (1918-1940) „Roczniki Historii Czasopiśmiennictwa Polskiego", nr 8/4, s. 521-536.

Pamiętniki emigrantów. Francja (1939), Warszawa: Instytut Gospodarstwa Społecznego.

Pamiętniki emigrantów. Kanada (1971), Warszawa: Książka i Wiedza.

Pamiętniki emigrantów. Stany Zjednoczone (1977), t.1, Warszawa: Książka i Wiedza.

Polonais aux champ. Lettres de femmes immigrées dan les campagnes françaises (1930-1935) (2015), S. Aprile, M. Laurent, J. Ponty (red.), Paris: Numilog.

Polish Setlers in Alberta. Reminiscences and Biographies (1979), J. Matejko (red.), Toronto: Polish Alliance Pres.

Polska diaspora (2001), A. Walaszek (red.), Kraków: Wydawnictwo Literackie.

Pomnik „Buraczanych dziewcząt” ma 75 lat, Federacja Polonia, (2015) http://www.federacja-polonia.dk/news-pomnik-buraczanych-dziewczat-ma-75-lat,108.html.

Praszałowicz D. (2009), Rola żeńskich zakonów religijnych w życiu skupisk polonijnych w Stanach Zjednoczonych, w: Polska - dwa światy. Kraj i Polonia. Materiały z Międzynarodowej Konferencji Naukowej 'Polacy w Ameryce Pótnocnej - 400 lecie', J.W. Wysocki, W. Gliński (red.), Warszaw: Wydawnictwo UKSW.

Praszałowicz D. (1999), Stosunki polsko-niemieckie na obczyźnie. Polscy i niemieccy imigranci w Milwaukee, Wisconsin (USA) 1860-1920, Kraków: Universitas.

Prymaka-Oniszek A. (2016), Bieżeństwo, „Karta” nr 86, s. 8-23.

Pula J.S. (2001), Polska diaspora w Stanach Zjednoczonych Ameryki do roku 1914, w: Polska diaspora, A. Walaszek (red.), Kraków: Wydawnictwo Literackie.

Radecki H. (1979), Ethnic Organizational Dynamics. The Polish Group in Canada, Waterloo, Ont.: Wilfrid Laurier University Press.

Sierakowska z Dalewskich A. (2018), Wspomnienia, J. Sikora-Kulesza, T Bariaškaitè (red.), Warszawa: Neriton 2010.

Skrabania D. (2018), „Ruhrpolen” - Polacy z Zagłębia Ruhry, Porta Polonica https://www.porta-polonica.de/pl/atlas-miejsc-pami\%C4\%99ci/ruhrpolen-polacy-z-zaglebia-ruhry.

Smolana K. (1983), Za ocean po lepsze życie, w: Dzieje Polonii w Ameryce Łacińskiej, Wrocław: Ossolineum.

Szramek T. (2008), Wczoraj i dziś Związku Polaków w Kanadzie [księga pamiątkowa], Toronto.

Thomas W.I., Znaniecki F, ( 1976) Chłop polski w Europie i Ameryce, t.: 5: Organizacja i dezorganizacja w Ameryce, Warszawa: Ludowa Spółdzielnia Wydawnicza.

Vincent I. (2006), Ciała i dusze, Wrocław: Wydawnictwo Dolnośląskie.

Walaszek, A. (1998), Między tradycją a kulturą masowej konsumpcji - kobiety i kultura życia codziennego społeczności polonijnych w USA w latach dwudziestych i trzydziestych XX wieku, w: Kobieta i kultura życia codziennego wiek XIX i XX, A. Żarnowska (red.), Warszawa, s. 279-292.

Walaszek A. (2002), Polskie imigrantki w miastach USA, „Przegląd Polonijny” nr 2, s. 25-41. Walaszek A. (1996), The Polish Women's Alliance in America: Between Feminism and Patriotism Immigrants and Their Children in the USA, 1898-1930, w: Ethnic Fraternalism in Immigrant Countries, M. Klemenčić (red.), Maribor: University of Maribor, s. 197-212. 
ANNA RECZYŃSKA

Próba przeglądu problemów, źródeł i opracowań na temat losów Polek na emigracji przed II wojną światową

Wkład Polek na emigracji w rozwój kultury i nauki polskiej. Materiały z sesji naukowej odbytej w Opolu 19-20 listopada 2004 roku (2004), T. Detyna, D. Kisielewicz (red.), Opole: Instytut Śląski.

Wojciechowski J. (1971), Życiorys własny robotnika, t. 1, Poznań: Wydawnictwo Poznańskie.

Zawistowicz-Adamska K. (1948), Społeczność wiejska. Doświadczenia i rozważania z badań terenowych $w$ Zaborowie, Łódź.

Zdunek W. (1982), Duszpasterstwo Polaków w Danii (1893-1978), „Studia Polonijne” nr 5, s. $145-177$. 